Article

\title{
Looking Beyond Energy Efficiency: An Applied Review of Water Desalination Technologies and an Introduction to Capillary-Driven Desalination
}

\author{
Seyedsaeid Ahmadvand ${ }^{1, *(1)}$, Behrooz Abbasi ${ }^{1, *}$, Babak Azarfar $^{1}$, Mohammed Elhashimi ${ }^{2}$, \\ Xiang Zhang ${ }^{2}\left(\mathbb{D}\right.$ and Bahman Abbasi ${ }^{2, *}$ \\ 1 Department of Mining and Metallurgical Engineering, University of Nevada, Reno, NV 89557, USA; \\ bazarfar@unr.edu \\ 2 School of Mechanical, Industrial and Manufacturing Engineering, Oregon State University, Bend, OR 97702, \\ USA; abbaselm@oregonstate.edu (M.E.); zhangxi8@oregonstate.edu (X.Z.) \\ * Correspondence: sahmadvand@unr.edu (S.A.); abbasi@unr.edu (B.A.); abbasib@oregonstate.edu (B.A.)
}

Received: 4 March 2019; Accepted: 1 April 2019; Published: 4 April 2019

\begin{abstract}
Most notable emerging water desalination technologies and related publications, as examined by the authors, investigate opportunities to increase energy efficiency of the process. In this paper, the authors reason that improving energy efficiency is only one route to produce more cost-effective potable water with fewer emissions. In fact, the grade of energy that is used to desalinate water plays an equally important role in its economic viability and overall emission reduction. This paper provides a critical review of desalination strategies with emphasis on means of using low-grade energy rather than solely focusing on reaching the thermodynamic energy limit. Herein, it is argued that large-scale commercial desalination technologies have by-and-large reached their engineering potential. They are now mostly limited by the fundamental process design rather than process optimization, which has very limited room for improvement without foundational change to the process itself. The conventional approach toward more energy efficient water desalination is to shift from thermal technologies to reverse osmosis (RO). However, RO suffers from three fundamental issues: (1) it is very sensitive to high-salinity water, (2) it is not suitable for zero liquid discharge and is therefore environmentally challenging, and (3) it is not compatible with low-grade energy. From extensive research and review of existing commercial and lab-scale technologies, the authors propose that a fundamental shift is needed to make water desalination more affordable and economical. Future directions may include novel ideas such as taking advantage of energy localization, surficial/interfacial evaporation, and capillary action. Here, some emerging technologies are discussed along with the viability of incorporating low-grade energy and its economic consequences. Finally, a new process is discussed and characterized for water desalination driven by capillary action. The latter has great significance for using low-grade energy and its substantial potential to generate salinity/blue energy.
\end{abstract}

Keywords: capillary-driven desalination; energy grade; viable desalination; emerging technologies

\section{Introduction}

Energy and freshwater production are heavily interconnected, termed the "water-energy nexus" [1-7]. Majority of the water on earth is in the oceans with high salinity and otherwise captured in the icecaps and glaciers [8], while most of human's energy usage ( $90 \%)$ originates from fossil fuels [9]. Water desalination is the manifestation of the water-energy nexus with all the strategic considerations regarding to the availability of the two (Figure 1) $[4,10]$. 

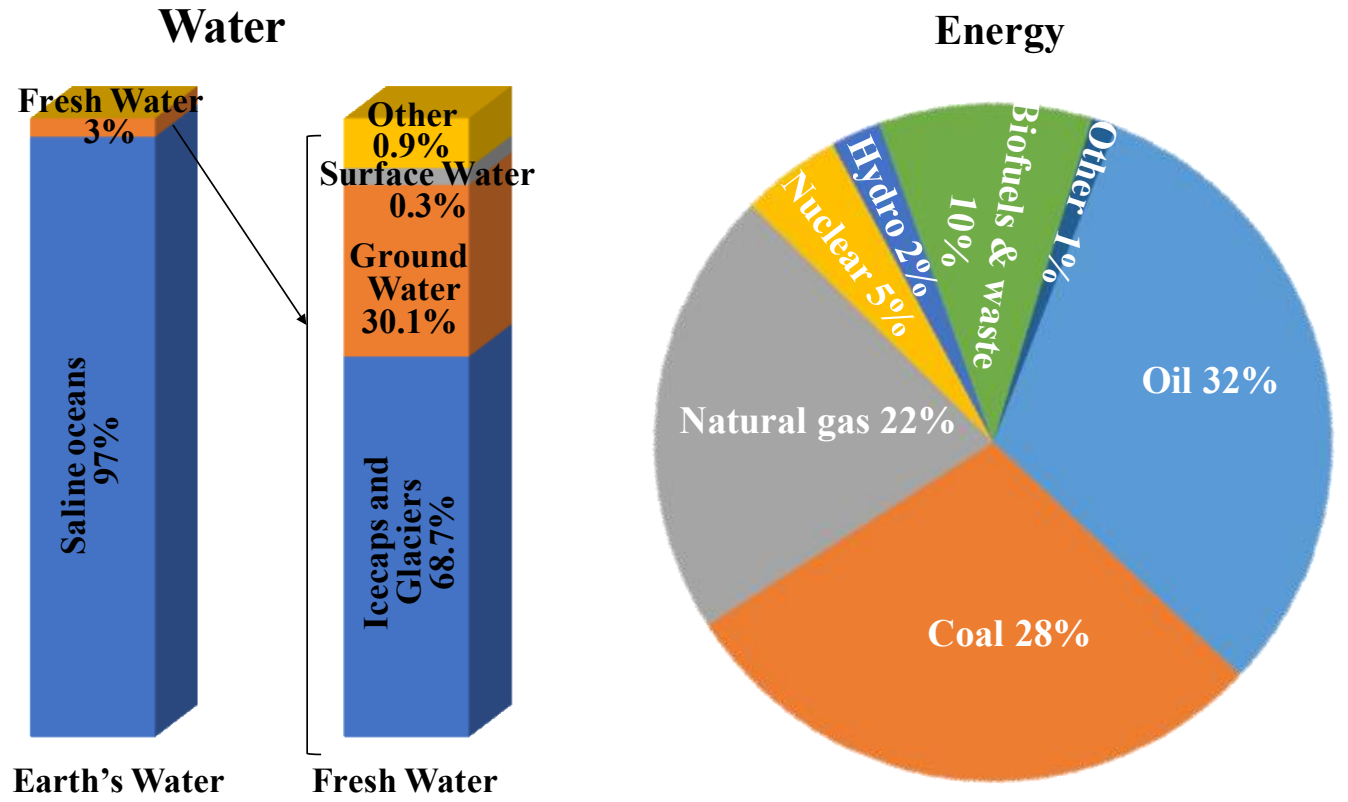

Figure 1. Current availability of water and energy resources $[2,4,9]$.

There are two groups of desalination currently in use: physical processes, such as reverse osmosis (RO), and chemical processes, such as the newer zerovalent iron (ZVI) technology, discovered in 2010 and just starting to be commercialized [11-17]. Throughout this study, desalination has been mainly reviewed as a purely physical process: the physical separation of salt and water [18-28]. In this sense, water desalination is fundamentally a thermodynamic process with a minimum required work that is intrinsic thereto. This is known as the minimum thermodynamic energy of separation (MTES); the lowest possible energy that is required to separate the solute from water [29]. Attempts to minimize energy consumption toward MTES are only beneficial if they are also economically viable [30].

Most researches are mainly focused on the energy and yield efficiency of desalination techniques, with inadequate emphasis on industrial needs [31-33]. In the industry, all desalination systems are designed to optimize the delivered full cycle cost to the consumer as opposed to energy consumption [34]. Despite intensive research in this area, the energy consumption of water, desalination technologies have not substantially changed within the past decade [35]. The energy efficiency of most current desalination technologies is controlled by the thermodynamics rather than the rate of the operation $[36,37]$. For instance, carbon nanotube membranes, with high permeability, increase the flux rate rather than the energy efficiency [38,39]. Also, energy efficiency often serves in favor of reducing the final cost, but in some cases this synergy is violated [35]. In the latter scenario, energy makes a major contribution to the operational expenditure (OpEx) but not necessarily to the capital expenditure (CapEx) [35]. For instance, some RO strategies offer more energy efficiency at the cost of adding extra high-pressure pumps, which leads to a higher levelized cost of water (LCOW) [35].

$\mathrm{RO}$ is considered to be the gold standard desalination technique [40-49]. However, recent attempts have not been successful to reduce the gap between the current RO technologies and MTES significantly [35]. Moreover, only high-grade energy is applicable in RO desalination and additional energy requirements for pre/post-treatments are disregarded in most energy analyses [31-33,50,51]. On the other hand, thermal desalination techniques are more agnostic to the salinity level of the intake water, and high-grade energy can be replaced by low-grade energy for the most part [52-55]. However, low-grade energy (i.e., low- to medium-temperature heat, up to $400{ }^{\circ} \mathrm{C}$ ) is harder to control, dissipates faster, and has lower exergy; entropy generation is more significant in thermal desalination plants [56-58]. One way to compensate for this energy inefficiency in thermal desalination is maximizing the latent heat recovery within the design or coupling the thermal plant with other thermal or power cycles, where heat is generated as a byproduct (e.g., power stations and supercomputer units) [59-62]. 
In either case, the rejected thermal energy from thermal generators, or so-called waste/process heat, is used to preheat the intake water or bring it to the saturation point [60-62]. The average byproduct waste heat $\left(33-56^{\circ} \mathrm{C}\right)$ is far below the saturation point of water in common thermal desalination plants $\left(70-100^{\circ} \mathrm{C}\right.$ ) [63]. This mismatch becomes less significant by lowering the saturation point of water through novel designs and/or localized evaporation [6,20,64-66].

Unlike boiling, evaporation pertains to liquid surface, hence, energy can be concentrated on the surface molecules to make evaporation more efficient [64]. However, bulk and surface molecules are interconnected, and dissipation delocalizes the surficial molecular energy [64]. Inspired by trees, capillary-driven water ascension (CDWA) [67] has been used in efficient energy generation, energy harvesting, and capillary-driven desalination (CDD) $[63,68,69]$. In this technique, solar energy is directly concentrated on the surficial molecules to optimize evaporation [64].

A wise choice of making an advantageous desalination plant also depends on the total dissolved solids (TDS) of the input and output water (Figure 2) [70-75]. Desalination technologies yield freshwater with much lower and brine with much higher salinity compared to the input $[76,77]$. However, with the increase of environmental concerns, the zero liquid discharge (ZLD) approach has drawn substantial interest among academics, industrial communities, and governments [78,79].

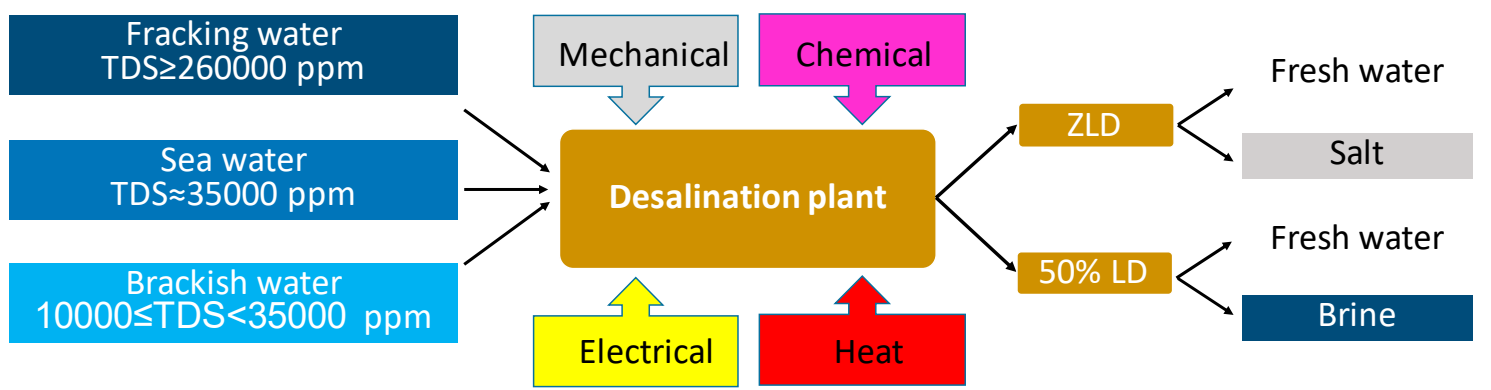

Figure 2. Inputs and outputs of a typical desalination process. TDS, total dissolved salts; LD, liquid discharge; ZLD, zero liquid discharge.

This review attempts to emphasize more on the fundamental strategies, which can fundamentally and yet practically improve desalination processes (Table 1). Few emerging technologies and strategies are discussed, which mainly increase the compatibility with low-grade energy via some fundamental strategies. The economic impact of those strategies is highlighted in two case studies. Finally, the newer CDD is introduced as a highly promising alternative to fundamentally improve desalination process, as it not only enhances the potential of using low-grade energy, but also can be employed to generate salinity energy.

Table 1. Fundamental strategies and their resulting impact in water desalination.

\begin{tabular}{lll}
\hline \multicolumn{1}{c}{ Fundamental Strategies } & \multicolumn{1}{c}{ Fundamental Impact } \\
\hline Surficial energy localization & - & $\begin{array}{l}\text { Increasing the vaporization efficiency } \\
\text { Downgrading the input energy }\end{array}$ \\
\hline Using degradable draw solution & - & $\begin{array}{l}\text { Transformation of reverse to forward osmosis } \\
\text { Downgrading the input energy }\end{array}$ \\
\hline Depressurized heating & - & $\begin{array}{l}\text { Downgrading the input energy } \\
\text { Increase scaling }\end{array}$ \\
\hline Pressurized heating & - & $\begin{array}{l}\text { Upgrading the input energy } \\
\text { Lowering saturation temperature }\end{array}$ \\
\hline
\end{tabular}


Table 1. Cont.

\begin{tabular}{lll}
\hline \multicolumn{1}{c}{ Fundamental Strategies } & \multicolumn{1}{c}{ Fundamental Impact } \\
\hline Oversaturation & - & $\begin{array}{l}\text { Salt crystallization; beneficial only if heating and } \\
\text { vaporization chambers are separated }\end{array}$ \\
\hline Capillary action & - & $\begin{array}{l}\text { Separating bulk and surface molecules } \\
\text { Electric potential generation }\end{array}$ \\
\hline Surface evaporation & - & $\begin{array}{l}\text { Minimization of energy loss in the bulk } \\
\text { Downgrading the input energy }\end{array}$ \\
\hline
\end{tabular}

\section{Thermodynamics of Desalination}

Dissolution of most salts in water is enthalpically negative $(\Delta H<0)$ and entropically positive $(\Delta S>0)$ and thus a spontaneous process $(\Delta G<0)[80-84]$.

$$
\Delta G=\Delta H-T \Delta S
$$

Desalination acts exactly in the opposite direction and the formerly released energy is the required MTES to drive the process [29]. In a reversible process, the output work is maximum and the input energy is minimum, and the input becomes the output, when the process is reversed [85-91]. Thus, the MTES is equivalent to the maximum energy produced by a mixing process before reaching equilibrium [85,88]. Following Raoult's Law for desalination of an ideal solution [92-96], the MTES $(\mathrm{kJ} / \mathrm{kg}$ product) can be obtained for an aqueous solution with a steady flow from,

$$
\text { MTES }=\frac{R T}{M_{p}}\left[\frac{x_{s} x_{w, p}-x_{w} x_{s, p}}{x_{w} x_{s, b}-x_{s} x_{w, b}}\left(x_{s, b} \ln \frac{x_{s, b}}{x_{s}}+x_{w, b} \ln \frac{x_{w, b}}{x_{w}}\right)+x_{s, p} \ln \frac{x_{s, p}}{x_{s}}+x_{w, p} \ln \frac{x_{w, p}}{x_{w}}\right]
$$

In Equation (2), $R$ is the ideal gas constant, $T$ is the temperature of the feed water intake, $M_{p}$ is the molar mass of the product water, and $x_{s}, x_{w}, x_{s, p}, x_{w, p}, x_{s, b}, x_{w, b}$ are the mole fractions of the salt and water in the feed water, product water, and brine, respectively [97]. This minimum energy depends only on the concentration of solutes regardless of any specific technology, mechanism, or number of stages $[98,99]$. Simple thermodynamic calculations reveal that the MTES is ideally $0.79 \mathrm{kWh} / \mathrm{m}^{3}$ for full and $1.09 \mathrm{kWh} / \mathrm{m}^{3}$ for $50 \%$ recovery of freshwater from typical seawater [100-105]. Using the second law efficiency, this value jumps to $1.9 \mathrm{kWh} / \mathrm{m}^{3}$ [51]. In reality, the most efficient state-of-the-art technologies run between 2.5 to $5 \mathrm{kWh} / \mathrm{m}^{3}$ [106]. The main goal of desalination is to minimize the discrepancy between the current technologies and the second law efficiency $\left(1.9 \mathrm{kWh} / \mathrm{m}^{3}\right)$ [107-109]. This discrepancy is attributed to entropy generation in real systems that is governed by the irreversibility of the process [58,110-114]. In contrast to energy, exergy is always destroyed within an irreversible process, generating entropy [115-118]. The aforementioned MTES values are associated with a full desalination of seawater with 35,000 ppm concentration of solutes [2,29,119-124].

Heat and work are considered low-grade (disordered) and high-grade (ordered) forms of energy, respectively [125-128]. The quality difference can be assigned to the two forms of energy, in which transforming one form to the other is more efficient than its opposite direction [129-134]. For instance, work can be efficiently converted to heat, e.g., electric heater with near- $100 \%$ efficiency, whereas maybe only half of the input heat (50\%) turns to work, e.g., heat engine [135-137].

$$
W=Q\left(1-\frac{T_{c}}{T_{h}}\right)
$$

Based on Equation (3), heat $(Q)$ can be transformed to work $(W)$ more efficiently, when the temperature difference between the hot $\left(T_{h}\right)$ and cold $\left(T_{c}\right)$ sources is higher. Also, production and storage of thermal energy is easier and cheaper, on the other hand electricity is often more environment 
friendly, i.e., less $\mathrm{CO}_{2}$ production [138-142]. Entropy generation $\left(S_{g}\right)$ in a thermal-based process can be evaluated from Equation (4) [58,110].

$$
S_{g}=Q\left(\frac{1}{T_{c}}-\frac{1}{T_{h}}\right)
$$

Entropy generation decreases as the process approaches the isothermal condition, i.e., $T_{c} \rightarrow T_{h}$.

$$
S_{g}=\frac{A}{\rho T}(\Delta p-\Delta \pi)^{2}
$$

In a membrane-based process however, entropy generation, per unit area, per $\mathrm{kg}$ fresh water, (Equation (5)) decreases as the process approaches the isobaric condition, i.e., hydraulic $(p)$ and osmotic $(\pi)$ pressures have similar magnitude at the end and beginning of the device, $\Delta p \rightarrow \Delta \pi[110,121,143-147]$.

\section{Conventional Desalination Technologies}

To treat large volumes of highly saline water, in locations where energy costs low or when a waste heat source is available, thermal desalination is still the most practical technique [148-151]. Thermal desalination commonly involve processes with large thermodynamic irreversibility $[31,152,153]$. High energy consumption and $\mathrm{CO}_{2}$ production are two major downsides of this approach [34,142]. In a thermal desalination process, water is vaporized and subsequently condensed in a separate vessel after being circulated to release the extra thermal energy including the latent heat. Evaporation consumed considerable energy but is in principle a reversible process, therefore, entropically favorable. Freeze desalination crystallizes water to form ice and separates salts from the ice; it is often both energetically and entropically unfavorable and thus less cost-effective with large irreversibilities [70,154-157]. However, in low temperature regions, freezing desalination eliminates the need for collecting and storing heat, where lack thereof is desirable [157-160]. High-temperature desalination suffers from two major risks: corrosion and scaling [161-164]. Over the decades, numerous thermal desalination techniques have been developed to address these risks, as well as to increase the efficiency of the process [103,165-170]. Those include multi-stage flash (MSF) distillation, multi-effect distillation (MED), vapor compression (VC), and humidification-dehumidification (HDH) [171-184]. The main difference between MED and MSF is the heat transfer and evaporation method; in the MED, seawater comes in direct contact with the heat exchanger, whereas in the MSF, energy transfer occurs via heat convection in seawater [167,185-190]. In both MED and MSF, the heat transfer between water and vapor occurs in multiple steps in an attempt to recover the latent heat (Figure 3a,b) [191-193]. This is done by compressing water vapor in a vapor compression (VC) device and passing hot air through liquid water and ultimate separation of the two in HDH [111,177,184,194-199]. In an efficient VC design, increasing the pressure of the vapor increases the condensation temperature, therefore, the vapor serves as the heating source for feed water; no need for an extra heat exchanger $[177,199]$. This heat exchange occurs directly between air and vapor in HDH desalination [194,198].

In membrane-based desalination, water is separated from its solute by membrane, a selective barrier which allows the separation of solvent and solute using a combination of diffusion and sieving [200-208]. Diffusion of chemicals from a lower to a higher concentration (chemical potential) causes osmotic pressure [209]. This diffusion can be reversed if a pressure higher than osmotic pressure is exerted to overcome the chemical potential flow [38,50,210-212]. In this sense, membrane designs which encourage sieving over diffusion are less energy intensive [202,203]. In other words, selectivity of new membrane designs should be of higher importance compared to their permeability. 


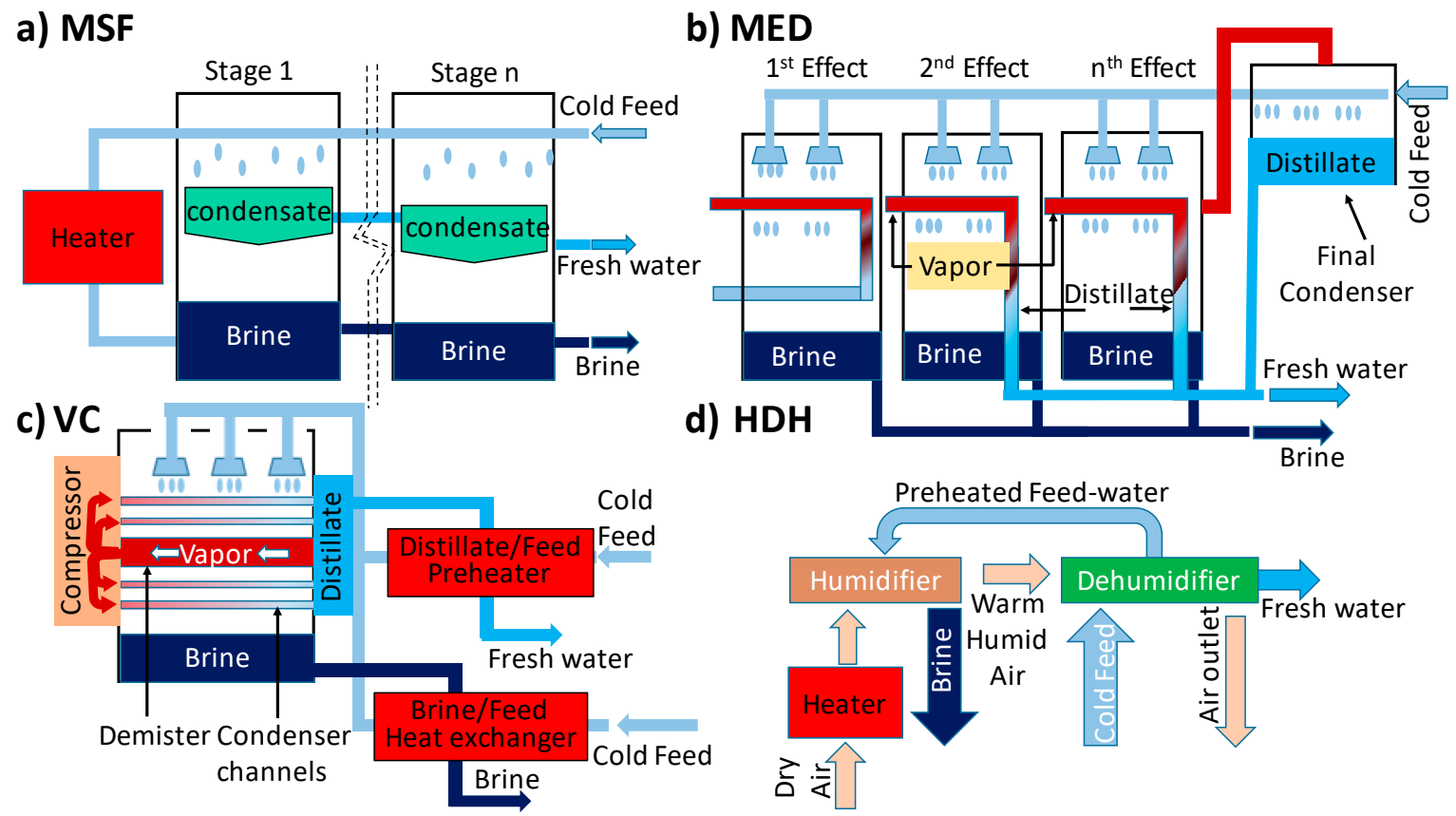

Figure 3. Typical scheme of thermal-based desalination modules; (a) multi-stage flash (MSF) distillation, (b) multi-effect distillation (MED), (c) vapor compression (VC), and (d) humidificationdehumidification $(\mathrm{HDH})$.

$\mathrm{RO}$ is a single-phase desalination technique (Figure 4a), which almost entirely requires high-grade energy [213-215]. RO is hard to go off-grid; significant (often economically unreasonable) number of solar panels is required, which makes it economically unviable [216-218]. Moreover, RO is better designed for continuous operation, while renewable energies fluctuate over time $[219,220]$. The lower recovery limit of $\mathrm{RO}$ is governed by the osmotic pressure and the upper limit by the chemical composition (scaling) and energy consumption [213,215,221]. Most researches have been conducted in designing new membranes with desired permeability [219,220,222]. However, a breakthrough to resolve the aforementioned issues cannot only be achieved within membrane developments [35]. Commonly, about one third of the cost of a RO process is energy consumption, 40\% CapEx, 25\% OpEx such as labor, maintenance, consumables, membrane replacement, and so on. Major engineering and construction cost include: $22 \%$ high-pressure pump and high alloy steel, $21 \%$ material, $18 \%$ civil engineering, $17 \%$ other services, $8 \%$ pretreatment, $7 \%$ intake and outfall, and $7 \%$ membrane and pressure vessels [152,223-227]. Accordingly, reducing the number of high-pressure pumps and the amount of high alloy steel cut the final cost more significantly compared to further membrane improvements. In RO, $40 \%$ of the flow energy stays in the brine, which can be recovered by pressure exchangers with very high efficiency [228]. Most of the energy loss occurs as the water passes through the membrane, i.e., large pressure drop $[215,229]$. Another issue regarding the energy loss or entropy generation is that the applied pressure has to increase within the device to overcome the osmotic pressure [230-232]. When the upper limit is set to ensure the water flow, pressure thus the entropy generation will be higher in most of the device than what it ought to be (hydraulic pressure $>>$ osmotic pressure) $[121,145,233,234]$. As already mentioned, adding more pumps with different pressures throughout the device is one solution for this issue, though usually economically unfavorable [35]. Electrodialysis (ED) is another commercialized membrane-based desalination technique (Figure 4b) [235-241]. Electrodialysis moves salts through charged membranes and traps them in alternating channels, using electric potential [242-245]. This technology is less energy intensive and more compatible with renewables, while less applicable for large scale and high salinity desalination [50,76,246,247]. 
a)

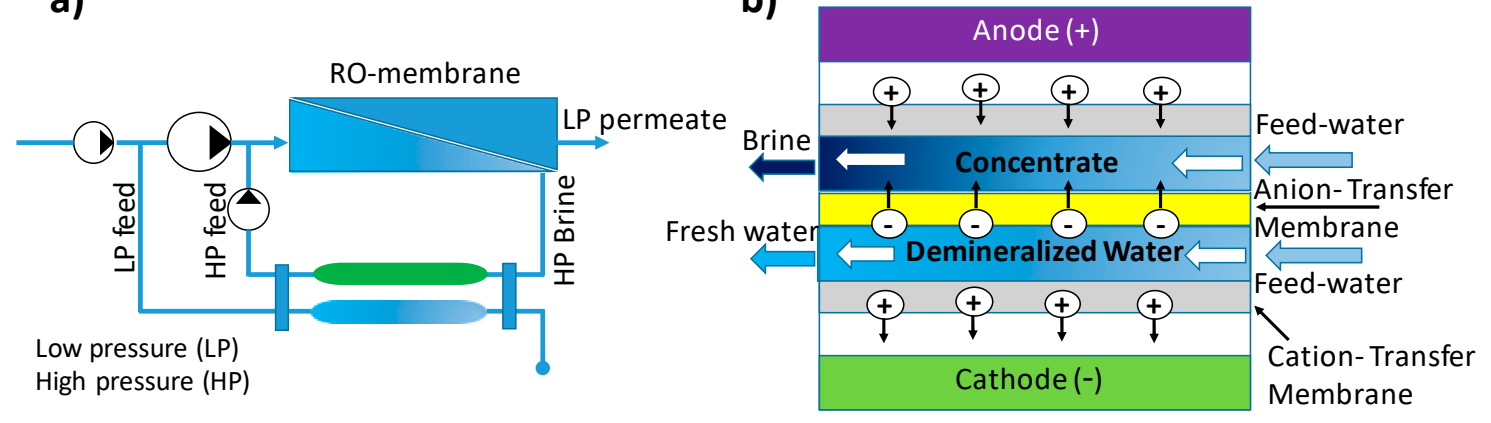

Figure 4. Typical scheme of membrane-based desalination modules; (a) reverse osmosis (RO), (b) electrodialysis (ED).

In the past decade, the dominance of RO over other desalination techniques has been due to its high scalability and relatively low energy requirement, neglecting the extra energy required for any additional treatment and the quality of this energy (Figure 5) [248-250]. In the following section, the merits of this dominance are investigated.

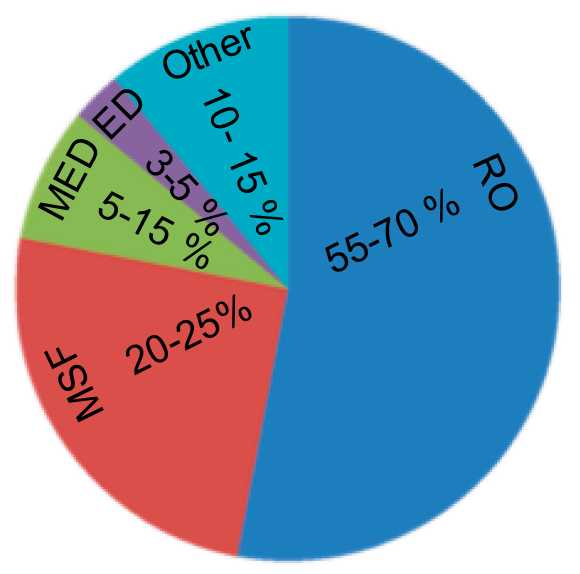

Figure 5. Contribution of different techniques in the current water desalination market.

\section{Emerging Technologies}

There are many concerns related to desalination technologies, namely, energy consumption and quality, environmental and technological compatibility, and more importantly economic considerations [251-258]. To address energy concerns, significant interest surrounds using waste heat, which in turn suffers from three major risks: (1) it requires capital investments for recuperators, (2) design modifications to account for heat load or temperature differences, and (3) low exergetic efficiency [31,32,35,259-263]. The first two can be managed by applying strategies in which hot and cold sources come into direct contact $[66,264-268]$. The third issue is more fundamental and can only be addressed if the desalination technique itself or some outside operational conditions provide a way to increase the potential of using waste heat $[58,184,269]$. Another step towards energy efficiency is to modify the plant to use ubiquitous renewable energies $[65,237,238]$. In addition to the above challenges, renewables are very dilute and intermittent [217,262]. To resolve the latter two, renewables should be harvested and stored in a most compatible and economical way [57,197,249,261]. In this sense, generating and storing low-grade energy from renewables is more compatible with thermal-based desalination $[52,54,77,269]$. Batch and semi-batch plant designs are other strategies to cope with intermittency of the renewables, both more compatible with thermal desalination [29].

Brine disposal and greenhouse gas production are two main environmental concerns [142,265]. Research on zero liquid discharge (ZLD) aims at eliminating brine disposal and can be better utilized 
in thermal desalination (Figure 6) $[78,255]$. In term of greenhouse gas production, membrane-based desalination is a cleaner technology in general, however, a well-designed combination of thermal desalination and a waste heat generating industry can be even cleaner $[63,269]$. Increasing compatibility with renewables is another step toward cleaner desalination [55,77,124,270-273]. The followings are a few innovative thermal-based and hybrid strategies, in most of which the ultimate goal is reconciliation between desalination and low-grade energy.

Figure 6 represents a distillation strategy that addresses the problems associated with traditional distillation: (1) scaling, (2) heat loss. Scaling reduces thermal conductivity and thus increases the amount of energy required to heat seawater up to saturation point $[55,274,275]$. It also results in serious maintenance issues that are costly and time consuming [276-279]. One strategy to address the issue of salt scaling is to utilize a pressurized chamber to prevent boiling and slow the formation of solid deposits scaling. Under pressure, seawater can be heated to very high temperatures. Maintaining pressure at $7 \times 10^{5}$ psi allows seawater to be heated to $300^{\circ} \mathrm{C}$ without boiling and thus reducing scaling. This is done by separating the heating of the water from vaporization of the water. Once heated to $300{ }^{\circ} \mathrm{C}$, the seawater is released through a nozzle into a flash chamber, where a portion of water turns into steam. The sudden decrease of pressure causes the hot seawater to separate into steam brine and salt. The brine and salt crystals fall to bottom of the chamber, where the salt crystals are separated from the brine and removed. This manages the scaling problem but does not solve the issue of the loss of thermal energy. To address the issue of thermal efficiency, a vapor compressor can be used to compress and heat the steam, so it condenses at higher temperature. The compressed hot steam enters a heat exchanger and provides majority of the thermal energy required to heat the seawater in the heating chamber. After exchanging heat with the seawater, the vapor condenses to warm distilled water. The second heat exchanger is added to heat the seawater and cool the distilled water [280]. Such strategies are best for places such as California, where environmental regulations and concerns about marine ecosystems withstand large-scale desalination as a solution to its water crisis [281].

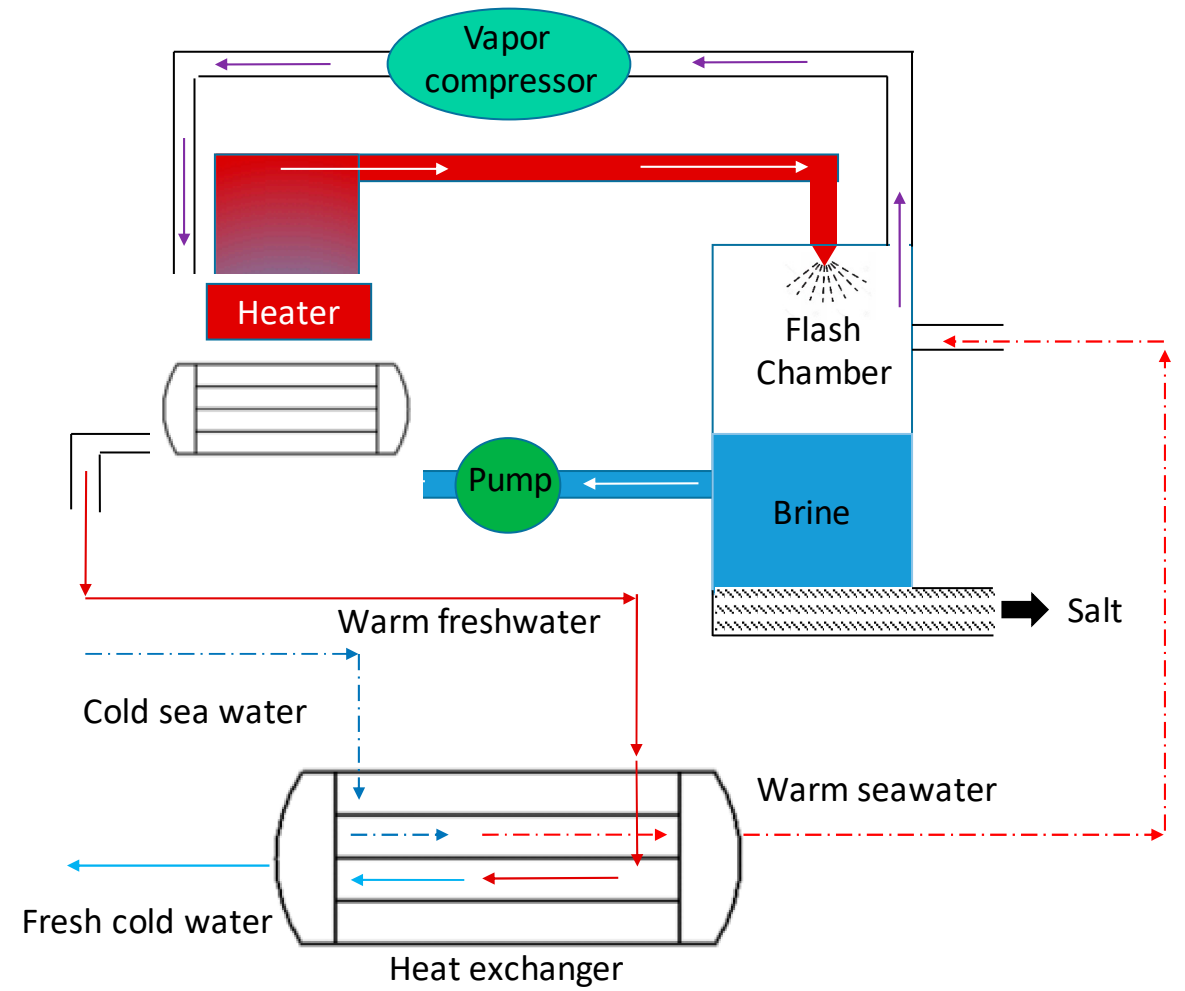

Figure 6. A thermal-based desalination strategy designed by EFD corporation. 
Using chemicals in water purification is of a great importance, especially for feed water that contains microorganisms and organic pollutants [282-288]. Variety of chemicals are used for different purposes, such as antimicrobial, degradative, coagulative, (photo-)catalysis, azeotrope breaking, and hydrophobic/hydrophilic agents [65,160,289-303]. Figure 7 however, represents a method to use chemicals in water desalination as a draw solution. Any high contaminated water sample can be used as a draw solution for a less contaminated sample (e.g., seawater for brackish water) in a forward osmosis (FO) process. FO can be used as a pretreatment to decrease the salinity of water without direct energy input. In the hybrid design shown in Figure 7a, ammonia and carbon dioxide gases are dissolved in water to create the draw solution. The advantage of using such a draw solution is that both gases can be recovered with the aid of low-grade heat at the final step (Figure $7 \mathrm{~b}$, phase 2) to obtain freshwater $[35,304,305]$.

a)

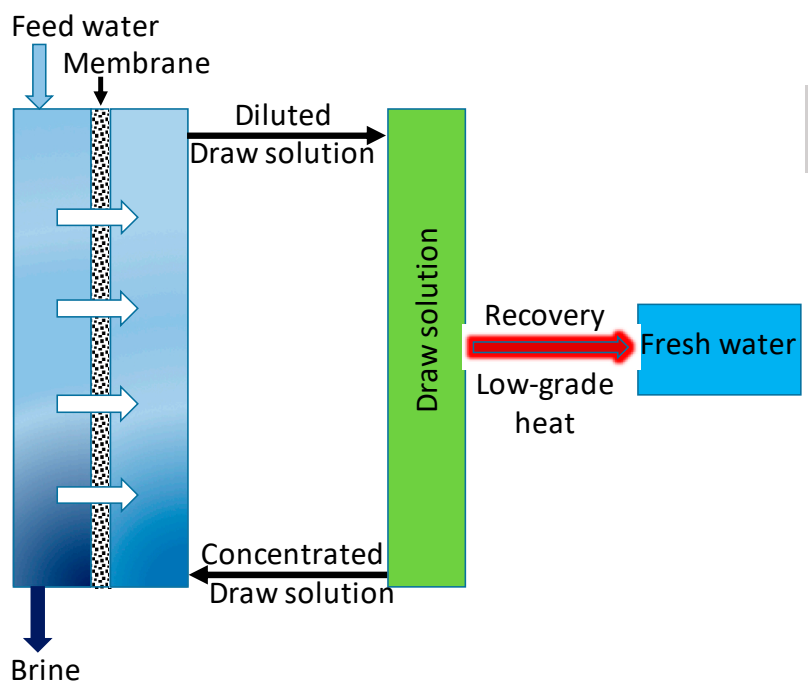

b)

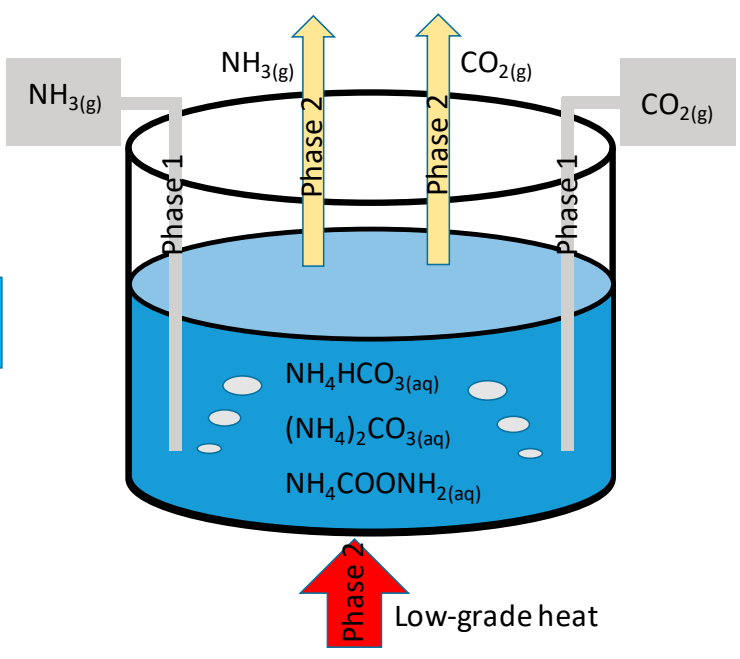

Figure 7. Hybridization of thermal- and membrane-based desalination; (a) whole plant, (b) draw solution.

Diffusion-driven desalination (DDD) process is a unique technology, which provides the means for low-temperature, low-pressure desalination and operates off of waste heat (Klausner et al. 2004, 2006, Khan et al. 2010; Alnaimat and Klausner 2012; Alnaimat et al. 2013). A schematic diagram of the DDD process and system is shown in Figure 8. The process includes three fluid circulation systems: freshwater, air/vapor, and saline water. Low pressure condensing steam heats the saline intake water in the saline water system. Afterwards, the heated feed water is transferred to the top of the diffusion tower. The feed water partially evaporates and diffuses into air. In the diffusion tower, the evaporation depends on the bulk air and concentration gradient at the vapor/ liquid interface. Consequently, the water is collected in a packed bed in the diffusion tower and a thin film of saline water forms over the packing material. The upward flowing air comes into contact with the water film through the diffusion tower and partially evaporates it, and the unevaporated water will be discharged. Low humidity cold air enters the bottom of the diffusion tower in the air/vapor system, being humidified and heated by the saline water as it moves upward through the tower. After leaving the diffusion tower, saturated air/vapor mixture comes into a direct contact with condenser, where it is dehumidified and cooled by cold water. The discharged water from the condenser will be cooled in a heat exchanger by the entering saline water that in the freshwater system. 


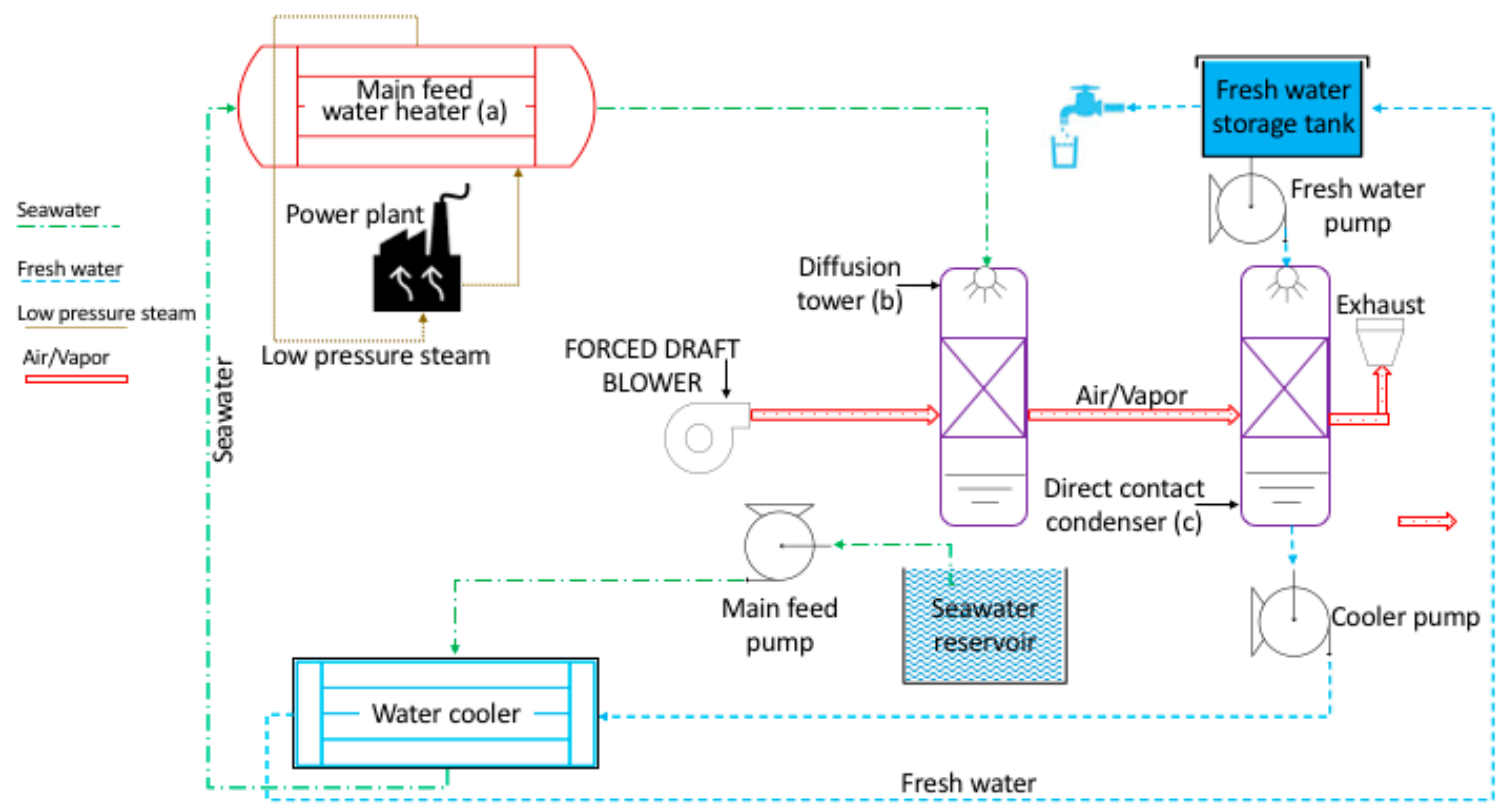

Figure 8. A schematic design of a diffusion-driven desalination (DDD) unit [306].

\section{Economic Analysis on Two Case Studies}

In this section, economic analyses are represented for two case studies based on: (1) in situ data from Marshal Islands, [307-312] (2) thermodynamic analysis for a novel desalination idea, designed by the authors. In economic terms, the contribution of each component (energy, CapEx, and OpEx) should be considered (in some analyses, energy and OpEx are in the same category). A cost breakdown for each component is shown in Figure 9, [152,224,313,314] as well as the energy quality spectrum from the lowest grade (low temperature heat) to the highest (electromagnetic) [315]. In membrane-based technologies, CapEx usually is the main contributor [316-318]. In thermal-based technologies, especially the traditional ones, cost of energy is the dominant component [250,319-322]. Using Equations (6)-(8), Table 2, and considering available waste heat, typical LCOW is calculated for MED and RO technologies. Table 2 shows that without using waste heat MED is $~ 2.5$ times more cost-intensive than RO. However, if MED is coupled with a source of waste heat, this ratio turns to MED's benefit, while energy consumption never drops and only the quality of energy changes.

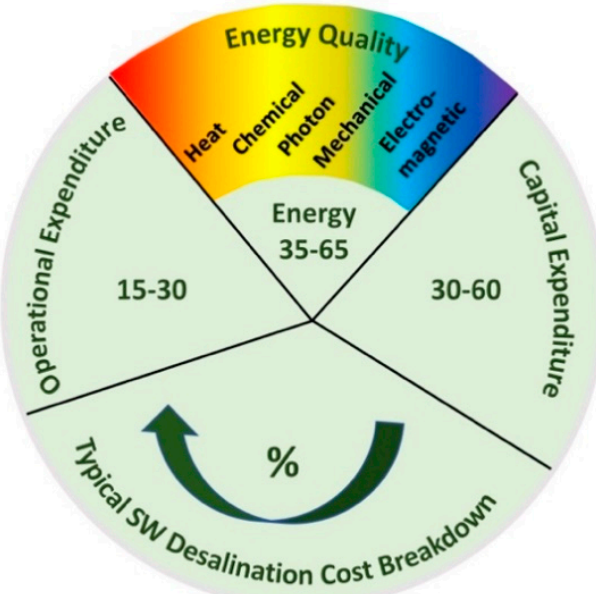

Figure 9. Typical seawater desalination cost breakdown and energy quality. 
Table 2. Input variables for the LCOW evaluation of MED and RO techniques.

\begin{tabular}{ccc}
\hline & MED & RO \\
\hline Electricity demand $\left(\mathrm{kWh} / \mathrm{m}^{3}\right)$ & 1.50 & 4.3 \\
Electricity cost $(\mathrm{USD} / \mathrm{kWh})$ & $0.2-0.5$ & $0.2-0.5$ \\
Heat demand $\left(\mathrm{kWh} / \mathrm{m}^{3}\right)$ & 52.6 & N/A \\
Fuel price $(\mathrm{USD} / \mathrm{lit})$ & $1.0-2.0$ & $\mathrm{~N} / \mathrm{A}$ \\
CapEx $\left(\mathrm{USD} / \mathrm{m}^{3} / \mathrm{day}\right)$ & 1700 & 2320 \\
OpEx (except electricity, USD $\left./ \mathrm{m}^{3}\right)$ & 0.3 & 0.3 \\
Lifetime $($ years) & 25 & 25 \\
LCOW $\left(\mathrm{USD} / \mathrm{m}^{3}\right)$ & $4.5-8$ & $1.7-3$ \\
LCOW & $0.98-1.45$ & N/A \\
\hline
\end{tabular}

In Equations (8)-(10), $I_{0}$ is the investment in USD, $A_{t}$ is the annual total costs in USD/annum, $M_{e l}$ is electricity output in $\mathrm{kWh}$ per year, $i$ is the interest rate, $n$ is the economic lifetime in years, and $t$ is year of operation $(1,2, \ldots, n)$ [312].

$$
\begin{gathered}
L C O E=\frac{I_{0}+\sum_{t=1}^{n} \frac{A_{t}}{(1+i)^{t}}}{\sum_{t=1}^{n} \frac{M_{e l}}{(1+i)^{t}}} \\
L C O W=\frac{I_{0}+\sum_{t=1}^{n} \frac{A_{t}}{(1+i)^{t}}}{\sum_{t=1}^{n} \frac{M_{w}}{(1+i)^{t}}} \\
A_{t}=O p E x+L C O E
\end{gathered}
$$

Figure 10 represents a novel desalination design to treat high salinity water in locations where water carries an initial pressure, such as fracking water [323-325]. This pressure can be used to run the water through different filters against gravity and push it all the way up to the top of distillation tower. Thereafter, by opening the upper faucets and blocking the adjustable sieving filter, the disposal pond is filled up to a certain level and a strong vacuum is made at the top of the tower without using any extra energy. This vacuum serves two purposes: (1) azeotrope breaking, (2) lowering the saturation point of water allowing the use of low-grade energy. At this point, volatile gases (if there is any) can be separated by increasing the temperature just several degrees Celsius. By setting up the maximum temperature at the saturation point of water $\left(40-50^{\circ} \mathrm{C}\right)$, nonvolatile substances will be left behind. Altering the temperature, volatile gases and water vapor can be separated using the lower pumps. At this stage, most salts have been already separated by the filters, and the brine collector trap the leftover salts. These traps can be cleaned when needed, leaving the re-vacuum operation for the upper pump. Whenever water level falls below a certain point the lower faucets will automatically open and fill up the pond again. The second phase is for further purification (if needed) takes advantage of interfacial evaporation on the surface of membrane. There is a cold and warm water stream on the top and bottom of the membrane, respectively, to trigger the interfacial evaporation. This interfacial evaporation is based on the thermal difference of the water streams on two sides of the membrane at each point, rather than the bulk temperature. Making the disposal pond right around the drilling well minimizes the gas leakage and pressure drop that is needed for the water elevation. Eventually the brine, including salts and nonvolatile substances, is collected in the pond and the brine tank. 


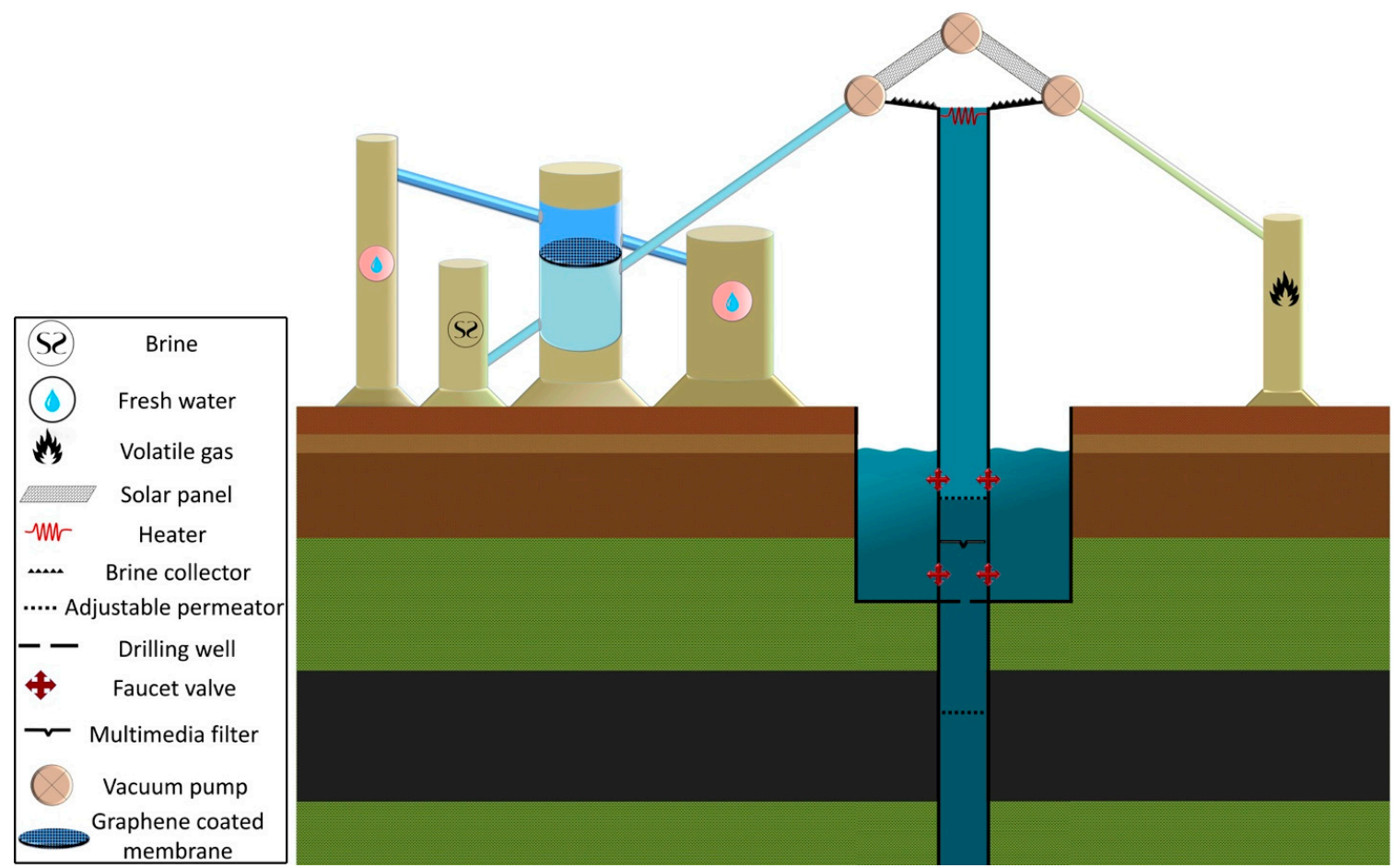

Figure 10. Schematic of the novel off-grid desalination plant, designed for off-grid treating of high salinity water in medium scale.

The calculated values for the LCOW demonstrate the economic flexibility that is achieved by coupling this process with low-grade/waste energy (Table 3). In this estimation, only the first phase (distillation tower) is considered and the benefits of azeotrope breaking is neglected.

Table 3. Operational parameters for the proposed design in comparison with conventional distillation.

\begin{tabular}{cccccc}
\hline $\begin{array}{c}\text { Water Back } \\
\text { Pressure }\end{array}$ & Tower Height & $\begin{array}{c}\text { Saturation } \\
\text { Temperature }\end{array}$ & $\begin{array}{c}\text { Saturation } \\
\text { Pressure }\end{array}$ & LCOE & LCOW \\
\hline$\sim 2 \mathrm{~atm}$ & $33 \mathrm{ft}$ & $40-50{ }^{\circ} \mathrm{C}$ & $0.12 \mathrm{~atm}$ & $\sim 60 \%$ & $50-90 \%$ \\
\hline
\end{tabular}

\section{Capillary-Driven Desalination}

Capillary effect can be used to avoid most of energy dissipation by separating the bulk and surface molecules $[64,68]$. This capillary action is generated by using microchannels with low thermal conductivity (insulating) and high hydrophilicity, which optimizes mass transfer and energy dissipation [63,64]. At each step, surficial water molecules are transferred through capillary microchannels to an absorptive and hydrophilic evaporation plate, where a low-grade energy source, such as sunlight or waste heat, provides sufficient energy for the phase change [64,68,326-329]. This idea was initially introduced by Ghasemi et al. to generate solar steam by heat localization (Figure 11) [64]. 
a

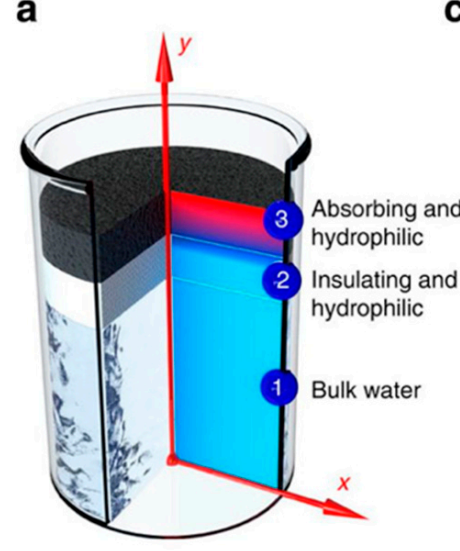

c

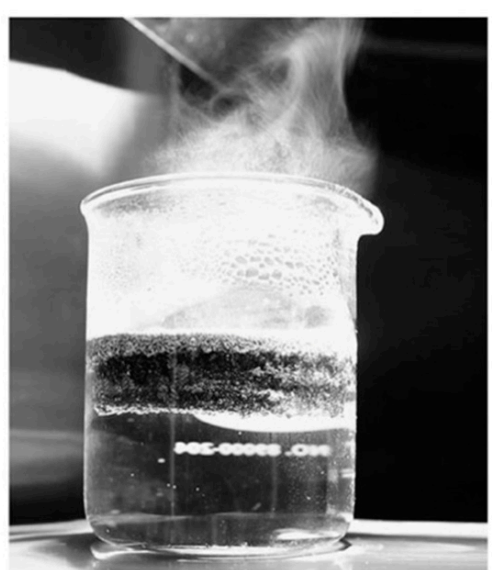

xfoliated graphite

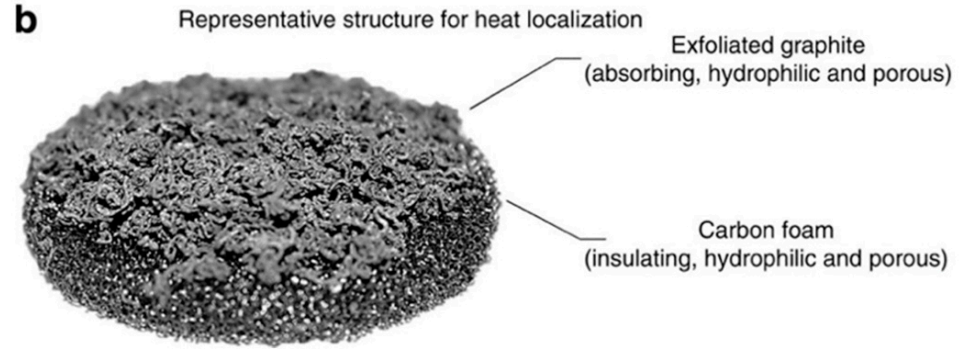

Figure 11. (a) A schematic structure and temperature distribution of a capillary-driven water ascension (CDWA) system. (b) The double layer structure consisting of capillary channels and evaporation plate, both being hydrophilic to drive the capillary ascending of water to the surface. (c) Enhanced steam generation under the solar illumination [64].

Traditionally, bulk water is uniformly heated up to a high temperature for vapor generation $[64,68]$. However, evaporation is a surface process, in which the high-energy salt water molecules at the surface are easily transported into the vapor phase. The conventional bulk-heating approach, therefore, leads to large amount of heat loss to the unevaporated part of water $[64,68]$. Bulk heating introduces a large lag and response time because of its large thermal inertia [63,64,69], but surface evaporation has minimal thermal inertia and responds very quickly to the change in the energy input, and allows for tighter process control for water quality and reducing energy consumption $[64,68,330]$. However, developing materials for long-term solar desalination through heat localization remains an open challenge due to fouling of the structure after a short period of time $[64,68,269]$. A porous polymer skeleton with embedded graphite flakes and carbon fibers has shown anti-fouling characteristics in the capillary micro-channels [68]. This cost-effective and durable material with easy fabrication procedure provides a path toward large-scale efficient solar desalination. Also, low-grade heat capillary-driven desalination is an efficient and environmentally friendly technology [64,68]. It has been demonstrated that, this strategy can not only be used in desalination and energy harvesting, but also in energy generation from the difference in salinity of water (saline energy) at the two ends of capillary microchannels (Figure 12) [331]. 


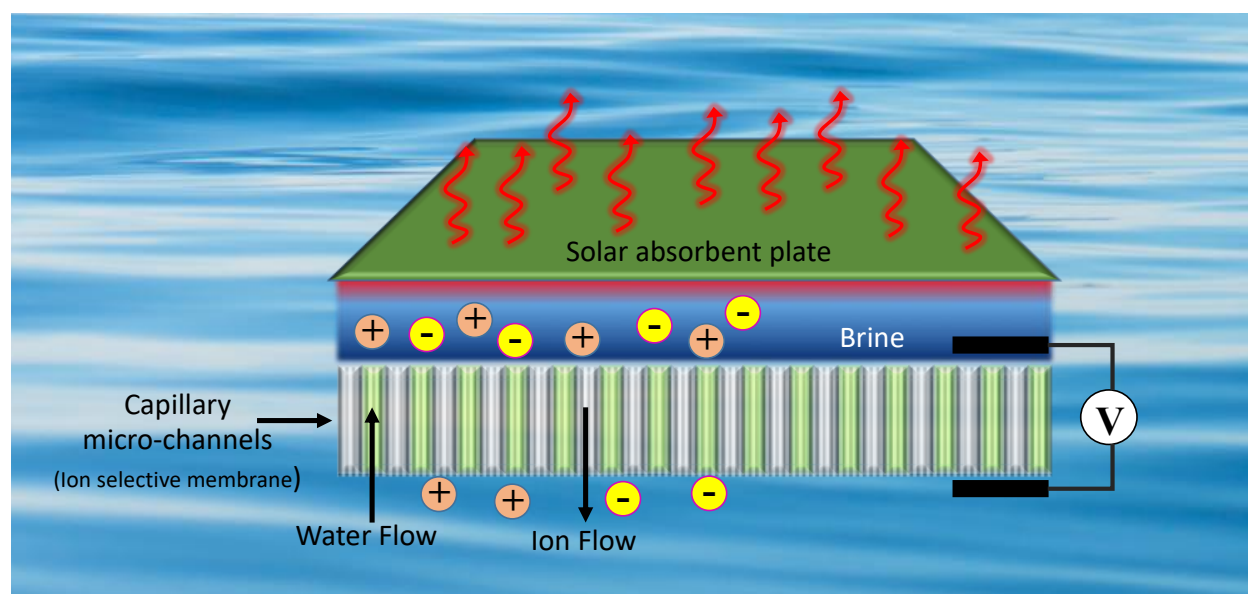

Figure 12. Schematic design of capillary-driven desalination/energy harvesting.

Table 4 summarizes the efficiency of CDD/CDWA systems made of different materials for capillary channel and evaporating plate, some of which being used for saline energy generation [331,332].

Table 4. Efficiency of CDD/CDWA systems.

\begin{tabular}{ccccc}
\hline Ref & Capillary Channel & Evaporator & $\begin{array}{c}\text { Irradiation/ } \\
\text { Temperature }\end{array}$ & Efficiency \\
\hline$[64]$ & Carbon foam & Exfoliated graphite & $10 \mathrm{~kW} \cdot \mathrm{m}^{-2}$ & $85 \%$ \\
{$[69]$} & Porous NiO disc & TiAlON-based & $1 \mathrm{~kW} \cdot \mathrm{m}^{-2}$ & $73 \%$ \\
{$[333]$} & Nano porous filter paper & Gold plasmonic nanostructure & $2.3 \mathrm{~kW} \cdot \mathrm{m}^{-2}$ & $87 \%$ \\
{$[269]$} & NiO wick & Naval brass & $34{ }^{\circ} \mathrm{C}$ & $65 \%$ \\
{$[68]$} & Rayon carbon fiber & Exfoliated graphite & $1 \mathrm{~kW} \cdot \mathrm{m}^{-2}$ & $63 \%$ \\
{$[330]$} & Cellulose fiber & Au/Ag-PFC & $1 \mathrm{~kW} \cdot \mathrm{m}^{-2}$ & $86 \%$ \\
{$[334]$} & Polytetrafluoroethylene & Graphene-based film & $1 \mathrm{~kW} \cdot \mathrm{m}^{-2}$ & $79 \%$ \\
{$[335]$} & Cotton rod-polystyrene & Graphene oxide & $1 \mathrm{~kW} \cdot \mathrm{m}^{-2}$ & $85 \%$ \\
{$[78]$} & Cellulosic filter paper & Graphene oxide (lifted) & $0.82 \mathrm{~kW} \cdot \mathrm{m}^{-2}$ & $78 \%$ \\
{$[336]$} & Basswood & Graphene oxide & $12 \mathrm{~kW} \cdot \mathrm{m}^{-2}$ & $83 \%$ \\
{$[337]$} & (Functionalized-)Chemically reduced-)Graphene oxide & $1 \mathrm{~kW} \cdot \mathrm{m}^{-2}$ & $38-48 \%$ \\
{$[338]$} & Hierarchical graphene foam & Graphene nanoparticles & $1 \mathrm{~kW} \cdot \mathrm{m}^{-2}$ & $93 \%$ \\
{$[339]$} & Polyacrylonitrile & CB-PMMA & $1 \mathrm{~kW} \cdot \mathrm{m}^{-2}$ & $72 \%$ \\
{$[331]$} & Nafion membrane & Carbon nanotube & $1 \mathrm{~kW} \cdot \mathrm{m}^{-2}$ & $75 \%$ \\
{$[340]$} & Pristine draft paper & Pencil-drawn-paper & $1 \mathrm{~kW} \cdot \mathrm{m}^{-2}$ & $80 \%$ \\
{$[67]$} & Basswood & Carbonized wood & $10 \mathrm{~kW} \cdot \mathrm{m}^{-2}$ & $87 \%$ \\
{$[341]$} & GO/NFC & CNT/GO & $1 \mathrm{~kW} \cdot \mathrm{m}^{-2}$ & $86 \%$ \\
{$[332]$} & Carbon cloth & Graphene & $1 \mathrm{~kW} \cdot \mathrm{m}^{-2}$ & $83 \%$ \\
\hline
\end{tabular}

\section{Conclusions}

Taken together, there is no single universal remedy to resolve the problems in the current desalination technologies. Full consideration of physicochemical, geographical, and economical parameters is required to choose one approach over the others. However, recent researches imply that CDD has made a good compromise between water production and energy consumption, and with more industrial intuitions it could alleviate the barriers hindering its wide-scale implementation. In this article we argued that most attempts aimed at lowering energy consumption toward MTES will not lead to commercially more viable desalination as they have not within the past decade. Instead, the main emphasis should be on increasing the ability of the system to use low-grade energy that is cheap and omnipresent. A successful strategy does not necessarily decrease the energy consumption, rather, it enables the system to take advantage of low-grade energy. This can require fundamental transformations to in the foundation of desalination technologies. Our economic analyses, as well as those of others, demonstrate that the main influence of using low-grade energy is not improvements in energy consumption but pronounced in the final cost of freshwater. This also has the major benefit 
of compatibility with low-grade energy from renewable energy source such as industrial waste heat. These can vastly impact renewable energies penetration, water production, and industrial efficiency, otherwise referred to as the water-energy nexus.

Author Contributions: Conceptualization, S.A. and B.A. (Bahman Abbasi); Methodology, S.A.; Software, S.A.; Validation, B.A. (Behrooz Abbasi) and B.A. (Bahman Abbasi); Formal Analysis, S.A.; Data Curation, S.A. and B.A. (Babak Azarfar); Writing-Original Draft Preparation, S.A.; Writing-Review \& Editing, B.A. (Behrooz Abbasi), B.A. (Bahman Abbasi), M.E, and X.Z.; Visualization, B.A. (Babak Azarfar); Supervision, B.A. (Bahman Abbasi); Project Administration, B.A. (Bahman Abbasi); Funding Acquisition, B.A. (Behrooz Abbasi) and B.A. (Bahman Abbasi).

Funding: This research was funded by the department of energy DOE grant number [DE-FOA-0001778 \& DE-FOA-0001858].

Acknowledgments: This work was supported by the DOE and ARPA-E for designing novel hybrid techniques in sea/fracking water desalination in the pilot scale.

Conflicts of Interest: The authors declare no competing financial interest.

\section{Abbreviation}

\begin{tabular}{|c|c|c|c|}
\hline A & Surface Area & $\mathrm{n}$ & Economic Life Time in years \\
\hline$A_{t}$ & Annual Total Cost in USD/Annum & OpEx & Operational Expenditure \\
\hline CapEx & Capital Expenditure & $\mathrm{P}$ & Pressure \\
\hline CDD & Capillary-Driven Desalination & Q & Heat \\
\hline CDWA & Capillary-Driven Water Ascension & $\mathrm{R}$ & Ideal Gas Constant \\
\hline $\mathrm{C}_{\mathrm{el}}$ & Cost of Electricity & $\mathrm{RO}$ & Reverse Osmosis \\
\hline DDD & Diffusion-Driven Desalination & $\mathrm{S}_{\mathrm{g}}$ & Entropy Generation \\
\hline DOE & Department of Energy & SWRO & Seawater Reverse Osmosis \\
\hline ED & Electrodialysis & $\mathrm{t}$ & Year of Operation \\
\hline $\mathrm{FO}$ & Forward Osmosis & $\mathrm{T}$ & Temperature \\
\hline G & Gibbs Free Energy (Exergy) & $\mathrm{T}_{\mathrm{c}}$ & Temperature of Cold Source \\
\hline $\mathrm{H}$ & Enthalpy Change & $\mathrm{TD}$ & Thermal Desalination \\
\hline $\mathrm{HDH}$ & Humidification Dehumidification & TDS & Total Dissolved salts \\
\hline i & Interest Rate & $\mathrm{T}_{\mathrm{h}}$ & Temperature of Hot Source \\
\hline $\mathrm{I}_{0}$ & Investment in USD & $\mathrm{VC}$ & Vapor Compression \\
\hline LCOE & Levelized Cost of Electricity & W & Work \\
\hline LCOW & Levelized Cost of Water & WH & Waste Heat \\
\hline LD & Liquid Discharge & $\mathrm{x}_{\mathrm{s}}$ & Mole Fraction of Salt in Feed Water \\
\hline MD & Membrane Desalination & $\mathrm{x}_{\mathrm{s}, \mathrm{b}}$ & Mole Fraction of Salt in Brine \\
\hline MED & Multi-Effect Distillation & $x_{s, p}$ & Mole Fraction of Salt in Product \\
\hline $\mathrm{M}_{\mathrm{el}}$ & Electricity Output in $\mathrm{kWh} /$ Year & $\mathrm{x}_{\mathrm{W}}$ & Mole Fraction of Water in Feed Water \\
\hline MSF & Multi-Stage Flash & $\mathrm{x}_{\mathrm{w}, \mathrm{b}}$ & Mole Fraction of Water in Brine \\
\hline $\mathrm{M}_{\mathrm{p}}$ & Molar Mass of Product Water & $\mathrm{x}_{\mathrm{w}, \mathrm{p}}$ & Mole Fraction of Water in Product \\
\hline MTES & $\begin{array}{l}\text { Minimum Thermodynamic Energy of } \\
\text { Separation }\end{array}$ & ZLD & Zero Liquid Discharge \\
\hline MVC & Mechanical Vapor Compression & $\pi_{\mathrm{i}}$ & Osmotic Pressure \\
\hline $\mathrm{M}_{\mathrm{W}}$ & Produced Water/Year & & \\
\hline
\end{tabular}

\section{References}

1. Schnoor, J.L. Water-Energy Nexus. Environ. Sci. Technol. 2011, 45, 5065. [CrossRef]

2. Li, Z.; Siddiqi, A.; Anadon, L.D.; Narayanamurti, V. Towards sustainability in water-energy nexus: Ocean energy for seawater desalination. Renew. Sustain. Energy Rev. 2018, 82, 3833-3847. [CrossRef]

3. Khalkhali, M.; Westphal, K.; Mo, W. The water-energy nexus at water supply and its implications on the integrated water and energy management. Sci. Total Environ. 2018, 636, 1257-1267. [CrossRef]

4. Sharif, M.N.; Haider, H.; Farahat, A.; Hewage, K.; Sadiq, R. Water Energy Nexus for Water Distribution Systems: A Literature Review. Environ. Rev. 2019. [CrossRef] 
5. Vakilifard, N.; Anda, M.; Bahri, P.A.; Ho, G. The role of water-energy nexus in optimising water supply systems-Review of techniques and approaches. Renew. Sustain. Energy Rev. 2018, 82, 1424-1432. [CrossRef]

6. Kim, S.; Piao, G.; Han, D.S.; Shon, H.K.; Park, H. Solar desalination coupled with water remediation and molecular hydrogen production: A novel solar water-energy nexus. Energy Environ. Sci. 2018, 11, $344-353$. [CrossRef]

7. Dai, J.; Wu, S.; Han, G.; Weinberg, J.; Xie, X.; Wu, X.; Song, X.; Jia, B.; Xue, W.; Yang, Q. Water-energy nexus: A review of methods and tools for macro-assessment. Appl. Energy 2018, 210, 393-408. [CrossRef]

8. Koutsoyiannis, D. Scale of water resources development and sustainability: small is beautiful, large is great. Hydrol. Sci. J. 2011, 56, 553-575. [CrossRef]

9. Khan, M.; Akhtar, U.; Shah, A. Technical analysis of energy sources, technologies and infrastructure of energy. In Proceedings of the 2014 International Conference on Energy Systems and Policies, ICESP 2014, Islamabad, Pakistan, 24-26 November 2014; pp. 1-5. [CrossRef]

10. Deshmukh, A.; Boo, C.; Karanikola, V.; Lin, S.; Straub, A.P.; Tong, T.; Warsinger, D.M.; Elimelech, M. Membrane distillation at the water-energy nexus: Limits, opportunities, and challenges. Energy Environ. Sci. 2018, 11, 1177-1196. [CrossRef]

11. Antia, D. Provision of Desalinated Irrigation Water by the Desalination of Groundwater within a Saline Aquifer. Hydrology 2016, 4, 1. [CrossRef]

12. Antia, D. Desalination of Groundwater and Impoundments using Nano-Zero Valent Iron, n-Fe0. Meteorol. Hydrol. Water Manag. 2015, 3, 21-38. [CrossRef]

13. Antia, D.D.J. ZVI (Fe0) desalination: catalytic partial desalination of saline aquifers. Appl. Water Sci. 2018, 8, 71. [CrossRef]

14. Antia, D.D.J. Desalination of water using ZVI (Fe0). Water (Switzerland) 2015, 7, 3671-3831. [CrossRef]

15. Antia, D. ZVI (Fe0) Desalination: Stability of Product Water. Resources 2016, 5, 15. [CrossRef]

16. Antia, D.D.J. Partial Desalination of Saline Irrigation Water Using $\left.\left[\mathrm{Fe}_{\mathrm{x}} \mathrm{O}_{\mathrm{y}}(\mathrm{OH})_{\mathrm{z}}\left(\mathrm{H}_{2} \mathrm{O}\right) \mathrm{m}\right) \mathrm{n}+/-\right]$. In Handbook of Ecomaterials; Springer International Publishing: Cham, Switzerland, 2019; pp. 323-352.

17. Antia, D.D.J. Irrigation water desalination using PVP (polyvinylpyrrolidone) coated n-Fe0 (ZVI, zero valent iron). New Polym. Nanocomposites Environ. Remediat. 2018, 541-600.

18. Cottier, F.R.; Nilsen, F.; Skogseth, R.; Tverberg, V.; Skarðhamar, J.; Svendsen, H. Arctic fjords: a review of the oceanographic environment and dominant physical processes. Geol. Soc. London, Spec. Publ. 2010, 344, 35-50. [CrossRef]

19. Atkinson, C.; Sansom, C.L.; Almond, H.J.; Shaw, C.P. Coatings for concentrating solar systems - A review. Renew. Sustain. Energy Rev. 2015, 45, 113-122. [CrossRef]

20. Hasani, H.; Ryan, K.; Amer, A.; Ricles, J.; Sause, R. Pre-Test Seismic Evaluation of Drywall Partition Walls Integrated With a Timber Rocking. In Proceedings of the Eleventh U.S. National Conference on Earthquake Engineering, Los Angeles, CA, USA, 25-29 June 2018.

21. Qasim, M.; Darwish, N.A.; Sarp, S.; Hilal, N. Water desalination by forward (direct) osmosis phenomenon: A comprehensive review. Desalination 2015, 374, 47-69. [CrossRef]

22. Mahmoudi, M.; Guerrero, F. The transmission of the US stock market crash of 2008 to the European stock markets: An applied time series investigation. Am. J. Econ. 2016, 6, 216-225. [CrossRef]

23. Mahmoudi, M.; Pingle, M. Bounded rationality, ambiguity, and choice. J. Behav. Exp. Econ. 2018, 75, 141-153. [CrossRef]

24. Foolad, F.; Franz, T.E.; Wang, T.; Gibson, J.; Kilic, A.; Allen, R.G.; Suyker, A. Feasibility analysis of using inverse modeling for estimating field-scale evapotranspiration in maize and soybean fields from soil water content monitoring networks. Hydrol. Earth Syst. Sci. 2017, 21, 1263-1277. [CrossRef]

25. Foolad, F.; Blankenau, P.; Kilic, A.; Allen, R.G.; Huntington, J.L.; Erickson, T.A.; Ozturk, D.; Morton, C.G.; Ortega, S.; Ratcliffe, I.; et al. Comparison of the Automatically Calibrated Google Evapotranspiration Application-EEFlux and the Manually Calibrated METRIC Application. Preprints 2018, 2018070040.

26. Mohammadrezaei, V.; Ebrahimi, M.; Beyramabadi, S.A. Calculation of concentration of alanine in water using the activity coefficient model and ab initio model. Bulg. Chem. Commun. 2017, 49, 106-108.

27. Mohammadrezaei, V.; Ebrahimi, M.; Beyramabadi, S.A. Study of the effect of molecular cluster size alanine concentrations in water by using the activity coefficient method and density functional theory. Bulg. Chem. Commun. 2017, 49, 147-151. 
28. Hasani, H.; Golafshani, A.A.; Estekanchi, H.E. Seismic performance evaluation of jacket-type offshore platforms using endurance time method considering soil-pile-superstructure interaction. Sci. Iran. 2017, 24, 1843-1854. [CrossRef]

29. Werber, J.R.; Deshmukh, A.; Elimelech, M. Can batch or semi-batch processes save energy in reverse-osmosis desalination? Desalination 2017, 402, 109-122. [CrossRef]

30. Karagiannis, I.C.; Soldatos, P.G. Water desalination cost literature: review and assessment. Desalination 2008, 223, 448-456. [CrossRef]

31. Mathioulakis, E.; Belessiotis, V.; Delyannis, E. Desalination by using alternative energy: Review and state-of-the-art. Desalination 2007, 203, 346-365. [CrossRef]

32. Subramani, A.; Jacangelo, J.G. Emerging desalination technologies for water treatment: A critical review. Water Res. 2015, 75, 164-187. [CrossRef]

33. Subramani, A.; Badruzzaman, M.; Oppenheimer, J.; Jacangelo, J.G. Energy minimization strategies and renewable energy utilization for desalination: A review. Water Res. 2011, 45, 1907-1920. [CrossRef]

34. Liyanaarachchi, S.; Shu, L.; Muthukumaran, S.; Jegatheesan, V.; Baskaran, K. Problems in seawater industrial desalination processes and potential sustainable solutions: A review. Rev. Environ. Sci. Biotechnol. 2014, 13, 203-214. [CrossRef]

35. Elimelech, M.; Phillip, W.A. The future of seawater desalination: Energy, technology, and the environment. Science 2011, 333, 712-717. [CrossRef] [PubMed]

36. Zhu, A.; Christofides, P.D.; Cohen, Y. Effect of thermodynamic restriction on energy cost Optimization of RO membrane water desalination. Ind. Eng. Chem. Res. 2009, 48, 6010-6021. [CrossRef]

37. Feinberg, B.J.; Ramon, G.Z.; Hoek, E.M. V Thermodynamic analysis of osmotic energy recovery at a reverse osmosis desalination plant. Environ. Sci. Technol. 2013, 47, 2982-2989. [CrossRef]

38. Lee, K.P.; Arnot, T.C.; Mattia, D. A review of reverse osmosis membrane materials for desalinationDevelopment to date and future potential. J. Memb. Sci. 2011, 370, 1-22. [CrossRef]

39. Zhao, H.; Qiu, S.; Wu, L.; Zhang, L.; Chen, H.; Gao, C. Improving the performance of polyamide reverse osmosis membrane by incorporation of modified multi-walled carbon nanotubes. J. Memb. Sci. 2014, 450, 249-256. [CrossRef]

40. Wang, L.; Sun, Y.; Chen, B. Rejection of haloacetic acids in water by multi-stage reverse osmosis: Efficiency, mechanisms, and influencing factors. Water Res. 2018, 144, 383-392. [CrossRef]

41. Chakraborty, P.; Ma, T.; Zahiri, A.H.; Cao, L.; Wang, Y. Carbon-Based Materials for Thermoelectrics. Adv. Condens. Matter Phys. 2018, 2018, 1-29. [CrossRef]

42. Sharifi, S.; Tivay, A.; Rezaei, S.M.; Zareinejad, M.; Mollaei-Dariani, B. Leakage fault detection in Electro-Hydraulic Servo Systems using a nonlinear representation learning approach. ISA Trans. 2018, 73, 154-164. [CrossRef] [PubMed]

43. Sharifi, S.; Rezaei, S.M.; Tivay, A.; Soleymani, F.; Zareinejad, M. Multi-class fault detection in electro-hydraulic servo systems using support vector machines. In Proceedings of the 4th RSI International Conference on Robotics and Mechatronics, ICRoM 2016, Tehran, Iran, 26-28 October 2016; pp. 252-257.

44. Sanaye, S.; Mohammadi Nasab, A. Modeling and optimizing a CHP system for natural gas pressure reduction plant. Energy 2012, 40, 358-369. [CrossRef]

45. Sanaye, S.; Nasab, A.M. Modeling and optimization of a natural gas pressure reduction station to produce electricity using genetic algorithm. 2010. Available online: https://www.semanticscholar.org/paper/Modelingand-optimization-of-a-natural-gas-pressure-Sanaye-Nasab/1dfc6d80d4b28e1f80857802b729c32ced6078d1 (accessed on 20 April 2019).

46. Lefebvre, O. Beyond NEWater: An insight into Singapore's water reuse prospects. Curr. Opin. Environ. Sci. Heal. 2017, 2, 26-31. [CrossRef]

47. Omarova, A.; Tussupova, K.; Berndtsson, R.; Kalishev, M.; Sharapatova, K. Protozoan parasites in drinking water: A system approach for improved water, sanitation and hygiene in developing countries. Int. J. Environ. Res. Public Health 2018, 15, 495. [CrossRef] [PubMed]

48. Falkenberg, T.; Saxena, D.; Kistemann, T. Impact of wastewater-irrigation on in-household water contamination. A cohort study among urban farmers in Ahmedabad, India. Sci. Total Environ. 2018, 639, 988-996. [CrossRef] 
49. Castro, C.; Cocuzza, M.; Lamberti, A.; Laurenti, M.; Pedico, A.; Pirri, C.F.; Rocca, V.; Borello, E.S.; Scaltrito, L.; Serazio, C.; et al. Graphene-Based Membrane Technology: Reaching Out to the Oil and Gas Industry. Geofluids 2018, 2018, 1-13. [CrossRef]

50. Charcosset, C. A review of membrane processes and renewable energies for desalination. Desalination 2009, 245, 214-231. [CrossRef]

51. Semiat, R. Energy issues in desalination processes. Environ. Sci. Technol. 2008, 42, 8193-8201. [CrossRef] [PubMed]

52. Mittelman, G.; Mouchtar, O.; Dayan, A. Large-scale solar thermal desalination plants: A review. Heat Transf. Eng. 2007, 28, 924-930. [CrossRef]

53. Khawaji, A.D.; Kutubkhanah, I.K.; Wie, J.M. Advances in seawater desalination technologies. Desalination 2008, 221, 47-69. [CrossRef]

54. Bundschuh, J.; Ghaffour, N.; Mahmoudi, H.; Goosen, M.; Mushtaq, S.; Hoinkis, J. Low-cost low-enthalpy geothermal heat for freshwater production: Innovative applications using thermal desalination processes. Renew. Sustain. Energy Rev. 2015, 43, 196-206. [CrossRef]

55. Esfahani, I.J.; Rashidi, J.; Ifaei, P.; Yoo, C. Efficient thermal desalination technologies with renewable energy systems: A state-of-the-art review. Korean J. Chem. Eng. 2016, 33, 351-387. [CrossRef]

56. Al-Kharabsheh, S.; Goswami, D.Y. Analysis of an innovative water desalination system using low-grade solar heat. Desalination 2003, 156, 323-332. [CrossRef]

57. Ranjan, K.R.; Kaushik, S.C. Energy, exergy and thermo-economic analysis of solar distillation systems: A review. Renew. Sustain. Energy Rev. 2013, 27, 709-723. [CrossRef]

58. Warsinger, D.M.; Mistry, K.H.; Nayar, K.G.; Chung, H.W.; Lienhard, J.H.V. Entropy generation of desalination powered by variable temperature waste heat. Entropy 2015, 17, 7530-7566. [CrossRef]

59. Kronenberg, G.; Lokiec, F. Low-temperature distillation processes in single-and dual-purpose plants. Desalination 2001, 136, 189-197. [CrossRef]

60. Dardour, S.; Nisan, S.; Charbit, F. Utilisation of waste heat from GT-MHR and PBMR reactors for nuclear desalination. Desalination 2007, 205, 254-268. [CrossRef]

61. Jouhara, H.; Anastasov, V.; Khamis, I. Potential of heat pipe technology in nuclear seawater desalination. Desalination 2009, 249, 1055-1061. [CrossRef]

62. Najafi, B.; Shirazi, A.; Aminyavari, M.; Rinaldi, F.; Taylor, R.A. Exergetic, economic and environmental analyses and multi-objective optimization of an SOFC-gas turbine hybrid cycle coupled with an MSF desalination system. Desalination 2014, 334, 46-59. [CrossRef]

63. Zhang, X.; Kan, W.; Jiang, H.; Chen, Y.; Cheng, T.; Jiang, H.; Hu, X. Capillary-driven low grade heat desalination. Desalination 2017, 410, 10-18. [CrossRef]

64. Ghasemi, H.; Ni, G.; Marconnet, A.M.; Loomis, J.; Yerci, S.; Miljkovic, N.; Chen, G. Solar steam generation by heat localization. Nat. Commun. 2014, 5, 4449. [CrossRef] [PubMed]

65. Abu Tarboush, B.J.; Rana, D.; Matsuura, T.; Arafat, H.A.; Narbaitz, R.M. Preparation of thin-film-composite polyamide membranes for desalination using novel hydrophilic surface modifying macromolecules. J. Memb. Sci. 2008, 325, 166-175. [CrossRef]

66. Li, B.; Sirkar, K.K. Novel membrane and device for direct contact membrane distillation-based desalination process. Ind. Eng. Chem. Res. 2004, 43, 5300-5309. [CrossRef]

67. Zhu, M.; Li, Y.; Chen, G.; Jiang, F.; Yang, Z.; Luo, X.; Wang, Y.; Lacey, S.D.; Dai, J.; Wang, C.; et al. Tree-Inspired Design for High-Efficiency Water Extraction. Adv. Mater. 2017, 29, 1704107. [CrossRef] [PubMed]

68. Kashyap, V.; Al-Bayati, A.; Sajadi, S.M.; Irajizad, P.; Wang, S.H.; Ghasemi, H. A flexible anti-clogging graphite film for scalable solar desalination by heat localization. J. Mater. Chem. A 2017, 5, 15227-15234. [CrossRef]

69. Liu, H.; Zhang, X.; Hong, Z.; Pu, Z.; Yao, Q.; Shi, J.; Yang, G.; Mi, B.; Yang, B.; Liu, X.; et al. A bioinspired capillary-driven pump for solar vapor generation. Nano Energy 2017, 42, 115-121. [CrossRef]

70. Shin, H.; Kalista, B.; Jeong, S.; Jang, A. Optimization of simplified freeze desalination with surface scraped freeze crystallizer for producing irrigation water without seeding. Desalination 2019, 452, 68-74. [CrossRef]

71. Miller, S.; Shemer, H.; Semiat, R. Energy and environmental issues in desalination. Desalination 2014, 366, 2-8. [CrossRef]

72. Stark, M.; Thompson, P. Water Use in Shale Gas Developments. Disruptive Sci. Technol. 2013, 1, $164-168$. [CrossRef] 
73. Estrada, J.M.; Bhamidimarri, R. A review of the issues and treatment options for wastewater from shale gas extraction by hydraulic fracturing. Fuel 2016, 182, 292-303. [CrossRef]

74. Ghobeity, A.; Mitsos, A. Optimal design and operation of desalination systems: New challenges and recent advances. Curr. Opin. Chem. Eng. 2014, 6, 61-68. [CrossRef]

75. Kolesar Kohl, C.A.; Capo, R.C.; Stewart, B.W.; Wall, A.J.; Schroeder, K.T.; Hammack, R.W.; Guthrie, G.D. Strontium isotopes test long-term zonal isolation of injected and Marcellus formation water after hydraulic fracturing. Environ. Sci. Technol. 2014, 48, 9867-9873. [CrossRef]

76. Kim, D.H. A review of desalting process techniques and economic analysis of the recovery of salts from retentates. Desalination 2011, 270,1-8. [CrossRef]

77. Ghaffour, N.; Bundschuh, J.; Mahmoudi, H.; Goosen, M.F.A. Renewable energy-driven desalination technologies: A comprehensive review on challenges and potential applications of integrated systems. Desalination 2015, 356, 94-114. [CrossRef]

78. Finnerty, C.; Zhang, L.; Sedlak, D.L.; Nelson, K.L.; Mi, B. Synthetic Graphene Oxide Leaf for Solar Desalination with Zero Liquid Discharge. Environ. Sci. Technol. 2017, 51, 11701-11709. [CrossRef]

79. Roberts, D.A.; Johnston, E.L.; Knott, N.A. Impacts of desalination plant discharges on the marine environment: A critical review of published studies. Water Res. 2010, 44, 5117-5128. [CrossRef] [PubMed]

80. Danielewicz-Ferchmin, I.; Ferchmin, A.R. Ion hydration and large electrocaloric effect. J. Solution Chem. 2002, 31, 81-96. [CrossRef]

81. Abell, T.N.; Bretz, S.L. Dissolving Salts in Water: Students' Particulate Explanations of Temperature Changes. J. Chem. Educ. 2018, 95, 504-511. [CrossRef]

82. Abell, T.N.; Bretz, S.L. Macroscopic Observations of Dissolving, Insolubility, and Precipitation: General Chemistry and Physical Chemistry Students' Ideas about Entropy Changes and Spontaneity. J. Chem. Educ. 2019, 96, 469-478. [CrossRef]

83. Yao, Y.; Kanai, Y. Free Energy Profile of $\mathrm{NaCl}$ in Water: First-Principles Molecular Dynamics with SCAN and Ï\%oB97X-V Exchange-Correlation Functionals. J. Chem. Theory Comput. 2018, 14, 884-893. [CrossRef] [PubMed]

84. Beauchamp, D.L.; Khajehpour, M. Probing the effect of water-water interactions on enzyme activity with salt gradients: A case-study using ribonuclease t1. J. Phys. Chem. B 2010, 114, 16918-16928. [CrossRef] [PubMed]

85. Zhao, D.; Deng, S.; Shao, Y.; Zhao, L.; Lu, P.; Su, W. A new energy analysis model of seawater desalination based on thermodynamics. Energy Procedia 2019, 158, 5472-5478. [CrossRef]

86. Piacentino, A. Application of advanced thermodynamics, thermoeconomics and exergy costing to a Multiple Effect Distillation plant: In-depth analysis of cost formation process. Desalination 2015, 371, 88-103. [CrossRef]

87. Qureshi, B.A.; Zubair, S.M.; Thiel, G.P.; Lienhard V, J.H. The reversed chemical engine cycle with application to desalination processes. Desalination 2016, 398, 256-264. [CrossRef]

88. Chung, H.W.; Nayar, K.G.; Swaminathan, J.; Chehayeb, K.M.; Lienhard V, J.H. Thermodynamic analysis of brine management methods: Zero-discharge desalination and salinity-gradient power production. Desalination 2017, 404, 291-303. [CrossRef]

89. Wang, L.; Biesheuvel, P.M.; Lin, S. Reversible thermodynamic cycle analysis for capacitive deionization with modified Donnan model. J. Colloid Interface Sci. 2018, 512, 522-528. [CrossRef]

90. Wu, G.; Kutlu, C.; Zheng, H.; Su, Y.; Cui, D. A study on the maximum gained output ratio of single-effect solar humidification-dehumidification desalination. Sol. Energy 2017, 157, 1-9. [CrossRef]

91. Akhatov, J.S. Energy and exergy analysis of solar PV powered reverse osmosis desalination. Appl. Sol. Energy 2017, 52, 265-270. [CrossRef]

92. Dong, G.; Kim, J.F.; Kim, J.H.; Drioli, E.; Lee, Y.M. Open-source predictive simulators for scale-up of direct contact membrane distillation modules for seawater desalination. Desalination 2017, 402, 72-87. [CrossRef]

93. Qian, Y.; Zhang, X.; Liu, C.; Zhou, C.; Huang, A. Tuning interlayer spacing of graphene oxide membranes with enhanced desalination performance. Desalination 2019, 460, 56-63. [CrossRef]

94. Li, K.; Hou, D.; Fu, C.; Wang, K.; Wang, J. Fabrication of PVDF nanofibrous hydrophobic composite membranes reinforced with fabric substrates via electrospinning for membrane distillation desalination. J. Environ. Sci. (China) 2019, 75, 277-288. [CrossRef] [PubMed]

95. Orfi, J.; Loussif, N.; Davies, P.A. Heat and mass transfer in membrane distillation used for desalination with slip flow. Desalination 2016, 381, 135-142. [CrossRef] 
96. Wang, Q.; Li, N.; Bolto, B.; Hoang, M.; Xie, Z. Desalination by pervaporation: A review. Desalination 2016, 387, 46-60. [CrossRef]

97. Cerci, Y.; Cengel, Y.; Wood, B.; Kahraman, N.; Karkas, E.S. Improving the thermodynamic and economic efficiencies of desalination plants: Minimum work required for desalination and case studies of four working plants. 2003.

98. Johnson, D.J.; Suwaileh, W.A.; Mohammed, A.W.; Hilal, N. Osmotic's potential: An overview of draw solutes for forward osmosis. Desalination 2018, 434, 100-120. [CrossRef]

99. Essalhi, M.; Khayet, M. Membrane Distillation (MD). Prog. Filtr. Sep. 2015, 61-99.

100. Astashov, A.G.; Samokhin, A.V.; Alekseev, N.V.; Litvinova, I.S.; Tsvetkov, Y.V. Heat and mass transfer in confined jet plasma reactor with peripheral vortex flow. J. Phys. Conf. Ser. 2018, 1134, 12004. [CrossRef]

101. Badran, A. Analysis of an Off-Grid Photovoltaic-Wind Hybrid Power System for Disi Water Pumping Project. Int. J. Therm. Environ. Eng. 2017, 14, 41-48.

102. Lee, H.; Ryu, H.; Lim, J.H.; Kim, J.O.; Dong Lee, J.; Kim, S. An optimal design approach of gas hydrate and reverse osmosis hybrid system for seawater desalination. Desalin. Water Treat. 2016, 57, 9009-9017. [CrossRef]

103. Babu, P.; Nambiar, A.; He, T.; Karimi, I.A.; Lee, J.D.; Englezos, P.; Linga, P. A Review of Clathrate Hydrate Based Desalination to Strengthen Energy-Water Nexus. ACS Sustain. Chem. Eng. 2018, 6, 8093-8107. [CrossRef]

104. Gupta, P.; Chandrasekharan Nair, V.; Sangwai, J.S. Phase Equilibrium of Methane Hydrate in the Presence of Aqueous Solutions of Quaternary Ammonium Salts. J. Chem. Eng. Data 2018, 63, 2410-2419. [CrossRef]

105. Zhang, Y.; Sheng, S.M.; Shen, X.D.; Zhou, X.B.; Wu, W.Z.; Wu, X.P.; Liang, D.Q. Phase Equilibrium of Cyclopentane + Carbon Dioxide Binary Hydrates in Aqueous Sodium Chloride Solutions. J. Chem. Eng. Data 2017, 62, 2461-2465. [CrossRef]

106. Mistry, K.H.; Lienhard, J.H. Generalized least energy of separation for desalination and other chemical separation processes. Entropy 2013, 15, 2046-2080. [CrossRef]

107. Post, J.W.; Huiting, H.; Cornelissen, E.R.; Hamelers, H.V.M. Pre-desalination with electro-membranes for SWRO. Desalin. Water Treat. 2011, 31, 296-304. [CrossRef]

108. Banat, F.; Qiblawey, H.; Nasser, Q.A.-. Design and Operation of Small-Scale Photovoltaic-Driven Reverse Osmosis (PV-RO) Desalination Plant for Water Supply in Rural Areas. Comput. Water, Energy Environ. Eng. 2012, 01, 31-36. [CrossRef]

109. Garcia, C.; Molina, F.; Zarzo, D. 7 year operation of a BWRO plant with raw water from a coastal aquifer for agricultural irrigation. Desalin. Water Treat. 2011, 31,331-338. [CrossRef]

110. Mistry, K.H.; McGovern, R.K.; Thiel, G.P.; Summers, E.K.; Zubair, S.M.; Lienhard, J.H. Entropy generation analysis of desalination technologies. Entropy 2011, 13, 1829-1864. [CrossRef]

111. Mistry, K.H.; Lienhard, J.H.; Zubair, S.M. Effect of entropy generation on the performance of humidificationdehumidification desalination cycles. Int. J. Therm. Sci. 2010, 49, 1837-1847. [CrossRef]

112. Chen, L.; Wu, C.; Sun, F. Finite time thermodynamic optimization or entropy generation minimization of energy systems. J. Non-Equilibrium Thermodyn. 1999, 24, 327-359. [CrossRef]

113. Narayan, G.P.; Lienhard V, J.H.; Zubair, S.M. Entropy generation minimization of combined heat and mass transfer devices. Int. J. Therm. Sci. 2010, 49, 2057-2066. [CrossRef]

114. Sciacovelli, A.; Verda, V.; Sciubba, E. Entropy generation analysis as a design tool - A review. Renew. Sustain. Energy Rev. 2015, 43, 1167-1181. [CrossRef]

115. Durmayaz, A.; Yavuz, H. Exergy analysis of a pressurized-water reactor nuclear-power plant. Appl. Energy 2001, 69, 39-57. [CrossRef]

116. Lior, N. Thoughts about future power generation systems and the role of exergy analysis in their development. Energy Convers. Manag. 2002, 43, 1187-1198. [CrossRef]

117. Mago, P.J.; Srinivasan, K.K.; Chamra, L.M.; Somayaji, C. An examination of exergy destruction in organic Rankine cycles. Int. J. Energy Res. 2008, 32, 926-938. [CrossRef]

118. Dincer, I.; Cengel, Y.A. Energy, entropy and exergy concepts and their roles in thermal engineering. Entropy 2001, 3, 116-149. [CrossRef]

119. Choi, S.; Chang, B.; Kang, J.H.; Diallo, M.S.; Choi, J.W. Energy-efficient hybrid FCDI-NF desalination process with tunable salt rejection and high water recovery. J. Memb. Sci. 2017, 541, 580-586. [CrossRef] 
120. Ahdab, Y.D.; Thiel, G.P.; Böhlke, J.K.; Stanton, J.; Lienhard, J.H. Minimum energy requirements for desalination of brackish groundwater in the United States with comparison to international datasets. Water Res. 2018, 141, 387-404. [CrossRef]

121. Lin, S.; Elimelech, M. Staged reverse osmosis operation: Configurations, energy efficiency, and application potential. Desalination 2015, 366, 9-14. [CrossRef]

122. Shahzad, M.W.; Burhan, M.; Ng, K.C. Pushing desalination recovery to the maximum limit: Membrane and thermal processes integration. Desalination 2017, 416, 54-64. [CrossRef]

123. Zarzo, D.; Prats, D. Desalination and energy consumption. What can we expect in the near future? Desalination 2018, 427, 1-9. [CrossRef]

124. Manju, S.; Sagar, N. Renewable energy integrated desalination: A sustainable solution to overcome future fresh-water scarcity in India. Renew. Sustain. Energy Rev. 2017, 73, 594-609. [CrossRef]

125. Tajima, H.; Hayashi, M. Finite-size effect on optimal efficiency of heat engines. Phys. Rev. E 2017, 96, 012128. [CrossRef] [PubMed]

126. Lostaglio, M.; Jennings, D.; Rudolph, T. Description of quantum coherence in thermodynamic processes requires constraints beyond free energy. Nat. Commun. 2015, 6, 6383. [CrossRef]

127. Wang, Y.; Zhang, S.M.; Deng, Y. Flexible low-grade energy utilization devices based on high-performance thermoelectric polyaniline/tellurium nanorod hybrid films. J. Mater. Chem. A 2016, 4, 3554-3559. [CrossRef]

128. Monroe, J.G.; Kumari, S.; Fairley, J.D.; Walters, K.B.; Berg, M.J.; Thompson, S.M. On the energy harvesting and heat transfer ability of a ferro-nanofluid oscillating heat pipe. Int. J. Heat Mass Transf. 2019, 132, 162-171. [CrossRef]

129. Bi, X.; Liu, P.; Li, Z. Thermo-dynamic analysis and simulation of a combined air and hydro energy storage (CAHES) system. Energy 2016, 116, 1385-1396. [CrossRef]

130. Baldvinsson, I.; Nakata, T. A feasibility and performance assessment of a low temperature district heating system - A North Japanese case study. Energy 2016, 95, 155-174. [CrossRef]

131. Liang, Y. Theoretical Analysis of a Novel Electricity-Cooling Cogeneration System Based on Waste Heat Recovery of Marine Engine. In Proceedings of the SAE Technical Paper Series, Detroit, MI, USA, 12-14 April 2016; Volume 1. [CrossRef]

132. Li, H.; Song, J.; Sun, Q.; Wallin, F.; Zhang, Q. A dynamic price model based on levelized cost for district heating. Energy Ecol. Environ. 2019, 4, 15-25. [CrossRef]

133. Xueliang, B.; Shaoxiang, Z. Specific Consumption Analysis of Vapor Compression Refrigeration System. In Proceedings of the ASME 2017 International Mechanical Engineering Congress and Exposition, Tampa, FL, USA, 3-9 November 2017; p. V006T08A077.

134. Lu, L.; Wang, X.; Wang, S.; Liu, X. A new concept of hybrid photovoltaic thermal (PVT) collector with natural circulation. Heat Mass Transf. und Stoffuebertragung 2017, 53, 2331-2339. [CrossRef]

135. Cheng, X.; Liang, X. Heat-work conversion optimization of one-stream heat exchanger networks. Energy 2012, 47, 421-429. [CrossRef]

136. De Vos, A. Efficiency of some heat engines at maximum-power conditions. Am. J. Phys. 2005, 53, 570-573. [CrossRef]

137. Benenti, G.; Casati, G.; Saito, K.; Whitney, R.S. Fundamental aspects of steady-state conversion of heat to work at the nanoscale. Phys. Rep. 2017, 694, 1-124. [CrossRef]

138. Sharma, A.; Tyagi, V.V.; Chen, C.R.; Buddhi, D. Review on thermal energy storage with phase change materials and applications. Renew. Sustain. Energy Rev. 2009, 13, 318-345. [CrossRef]

139. Gil, A.; Medrano, M.; Martorell, I.; Lázaro, A.; Dolado, P.; Zalba, B.; Cabeza, L.F. State of the art on high temperature thermal energy storage for power generation. Part 1-Concepts, materials and modellization. Renew. Sustain. Energy Rev. 2010, 14, 31-55. [CrossRef]

140. Zhang, Y.; Zhou, G.; Lin, K.; Zhang, Q.; Di, H. Application of latent heat thermal energy storage in buildings: State-of-the-art and outlook. Build. Environ. 2007, 42, 2197-2209. [CrossRef]

141. Vince, F.; Aoustin, E.; Bréant, P.; Marechal, F. LCA tool for the environmental evaluation of potable water production. Desalination 2008, 220, 37-56. [CrossRef]

142. Glade, H.; Meyer, J.H.; Will, S. The release of CO2 in MSF and ME distillers and its use for the recarbonation of the distillate: A comparison. Desalination 2005, 182, 99-110. [CrossRef] 
143. Tchanche, B.F.; Lambrinos, G.; Frangoudakis, A.; Papadakis, G. Exergy analysis of micro-organic Rankine power cycles for a small scale solar driven reverse osmosis desalination system. Appl. Energy 2010, 87, 1295-1306. [CrossRef]

144. Yip, N.Y.; Elimelech, M. Thermodynamic and energy efficiency analysis of power generation from natural salinity gradients by pressure retarded osmosis. Environ. Sci. Technol. 2012, 46, 5230-5239. [CrossRef]

145. Seppälä, A.; Lampinen, M.J. Thermodynamic optimizing of pressure-retarded osmosis power generation systems. J. Memb. Sci. 1999, 161, 115-138. [CrossRef]

146. Narayan, G.P.; McGovern, R.K.; Zubair, S.M.; Lienhard, J.H. High-temperature-steam-driven, varied-pressure, humidification-dehumidification system coupled with reverse osmosis for energy-efficient seawater desalination. Energy 2012, 37, 482-493. [CrossRef]

147. Sharqawy, M.H.; Zubair, S.M.; Lienhard, J.H. Second law analysis of reverse osmosis desalination plants: An alternative design using pressure retarded osmosis. Energy 2011, 36, 6617-6626. [CrossRef]

148. Qiblawey, H.M.; Banat, F. Solar thermal desalination technologies. Desalination 2008, 220, 633-644. [CrossRef]

149. Al-Sahali, M.; Ettouney, H. Developments in thermal desalination processes: Design, energy, and costing aspects. Desalination 2007, 214, 227-240. [CrossRef]

150. Ng, K.C.; Thu, K.; Kim, Y.; Chakraborty, A.; Amy, G. Adsorption desalination: An emerging low-cost thermal desalination method. Desalination 2013, 308, 161-179. [CrossRef]

151. Schwarzer, K.; Vieira, M.E.; Faber, C.; Müller, C. Solar thermal desalination system with heat recovery. Desalination 2001, 137, 23-29. [CrossRef]

152. Ghaffour, N.; Missimer, T.M.; Amy, G.L. Technical review and evaluation of the economics of water desalination: Current and future challenges for better water supply sustainability. Desalination 2013, 309, 197-207. [CrossRef]

153. García-Rodríguez, L. Seawater desalination driven by renewable energies: A review. Desalination 2002, 143, 103-113. [CrossRef]

154. Zambrano, A.; Ruiz, Y.; Hernández, E.; Raventós, M.; Moreno, F.L. Freeze desalination by the integration of falling film and block freeze-concentration techniques. Desalination 2018, 436, 56-62. [CrossRef]

155. Walmsley, T.G.; Varbanov, P.S.; Su, R.; Klemeš, J.J.; Ong, C.W.; Chen, C.-L. Techno-Economic Analysis of Seawater Freezing Desalination using Liquefied Natural Gas. Chem. Eng. Trans. 2018, 70, 373-379.

156. Chang, J.; Zuo, J.; Lu, K.J.; Chung, T.S. Membrane development and energy analysis of freeze desalination-vacuum membrane distillation hybrid systems powered by LNG regasification and solar energy. Desalination 2019, 449, 16-25. [CrossRef]

157. Yang, H.; Sun, Z.; Zhan, Z.; Zhang, H.; Yao, Y. Effects of watering parameters in a combined seawater desalination process. Desalination 2018, 425, 77-85. [CrossRef]

158. Xie, C.; Zhang, L.; Liu, Y.; Lv, Q.; Ruan, G.; Hosseini, S.S. A direct contact type ice generator for seawater freezing desalination using LNG cold energy. Desalination 2018, 435, 293-300. [CrossRef]

159. Kalista, B.; Shin, H.; Cho, J.; Jang, A. Current development and future prospect review of freeze desalination. Desalination 2018, 447, 167-181. [CrossRef]

160. Cheng, J.; Zhang, Z.; Zheng, Z.; Lv, G.; Wang, L.; Tian, B.; Hua, Y. Antioxidative and hepatoprotective activities of deinoxanthin-rich extract from Deinococcus radiodurans R1 against carbon tetrachloride-induced liver injury in mice. Trop. J. Pharm. Res. 2014, 13, 573-580. [CrossRef]

161. Rahmani, K.; Jadidian, R.; Haghtalab, S. Evaluation of inhibitors and biocides on the corrosion, scaling and biofouling control of carbon steel and copper-nickel alloys in a power plant cooling water system. Desalination 2016, 393, 174-185. [CrossRef]

162. Touir, R.; Dkhireche, N.; Ebn Touhami, M.; Lakhrissi, M.; Lakhrissi, B.; Sfaira, M. Corrosion and scale processes and their inhibition in simulated cooling water systems by monosaccharides derivatives. Part I: EIS study. Desalination 2009, 249, 922-928. [CrossRef]

163. El-Dahshan, M.E. Corrosion and scaling problems present in some desalination plants in Abu Dhabi. Desalination 2001, 138, 371-377.

164. Abdel-Gaber, A.M.; Abd-El-Nabey, B.A.; Khamis, E.; Abd-El-Khalek, D.E. A natural extract as scale and corrosion inhibitor for steel surface in brine solution. Desalination 2011, 278, 337-342. [CrossRef]

165. Ullah, I.; Rasul, M.G. Recent developments in solar thermal desalination technologies: A review. Energies 2019, 12, 119. 
166. Jia, Y.; Alva, G.; Fang, G. Development and applications of photovoltaic-thermal systems: A review. Renew. Sustain. Energy Rev. 2019, 102, 249-265. [CrossRef]

167. Zhao, J.; Wang, M.; Lababidi, H.M.S.; Al-Adwani, H.; Gleason, K.K. A review of heterogeneous nucleation of calcium carbonate and control strategies for scale formation in multi-stage flash (MSF) desalination plants. Desalination 2018, 442, 75-88. [CrossRef]

168. Brogioli, D.; La Mantia, F.; Yip, N.Y. Thermodynamic analysis and energy efficiency of thermal desalination processes. Desalination 2018, 428, 29-39. [CrossRef]

169. Jani, H.K.; Modi, K.V. A review on numerous means of enhancing heat transfer rate in solar-thermal based desalination devices. Renew. Sustain. Energy Rev. 2018, 93, 302-317. [CrossRef]

170. Srithar, K.; Rajaseenivasan, T. Recent fresh water augmentation techniques in solar still and HDH desalination-A review. Renew. Sustain. Energy Rev. 2018, 82, 629-644. [CrossRef]

171. Yuan, G.; Wang, Z.; Li, H.; Li, X. Experimental study of a solar desalination system based on humidification-dehumidification process. Desalination 2011, 277, 92-98. [CrossRef]

172. Narayan, G.P.; Sharqawy, M.H.; Summers, E.K.; Lienhard, J.H.; Zubair, S.M.; Antar, M.A. The potential of solar-driven humidification-dehumidification desalination for small-scale decentralized water production. Renew. Sustain. Energy Rev. 2010, 14, 1187-1201. [CrossRef]

173. Sharaf, M.A.; Nafey, A.S.; García-Rodríguez, L. Exergy and thermo-economic analyses of a combined solar organic cycle with multi effect distillation (MED) desalination process. Desalination 2011, 272, 135-147. [CrossRef]

174. Alarcón-Padilla, D.C.; García-Rodríguez, L.; Blanco-Gálvez, J. Design recommendations for a multi-effect distillation plant connected to a double-effect absorption heat pump: A solar desalination case study. Desalination 2010, 262, 11-14. [CrossRef]

175. Al-Hallaj, S.; Farid, M.M.; Tamimi, A.R. Solar desalination with a humidification - dehumidification cycle: Performance of the unit. Desalination 1998, 120, 273-280. [CrossRef]

176. Nafey, A.S.; Fath, H.E.S.; El-Helaby, S.O.; Soliman, A. Solar desalination using humidification-dehumidification processes. Part II. An experimental investigation. Energy Convers. Manag. 2004, 45, 1263-1277. [CrossRef]

177. Tleimat, B.W.; Howe, E.D.; Laird, A.D.K. An assessment of vapor compression distillation. Desalination 1967, 2, 287-298. [CrossRef]

178. Mabrouk, A.A.; Nafey, A.S.; Fath, H.E.S. Analysis of a new design of a multi-stage flash-mechanical vapor compression desalination process. Desalination 2007, 204, 482-500. [CrossRef]

179. Darwish, M.A.; Al-Najem, N.M. Energy consumption by multi-stage flash and reverse osmosis desalters. Appl. Therm. Eng. 2000, 20, 399-416. [CrossRef]

180. Hamed, O.A.; Al-Sofi, M.A.K.; Imam, M.; Mustafa, G.M.; Ba Mardouf, K.; Al-Washmi, H. Thermal performance of multi-stage flash distillation plants in Saudi Arabia. Desalination 2000, 128, 281-292. [CrossRef]

181. El-Dessouky, H.; Alatiqi, I.; Ettouney, H. Process synthesis: the multi-stage flash desalination system. Desalination 1998, 115, 155-179. [CrossRef]

182. El-Dessouky, H.T.; Ettouney, H.M.; Al-Roumi, Y. Multi-stage flash desalination: Present and future outlook. Chem. Eng. J. 1999, 73, 173-190. [CrossRef]

183. Spiegler, K.S.; El-Sayed, Y.M. The energetics of desalination processes. Desalination 2001, 134, $109-128$. [CrossRef]

184. Senatore, S.J. Vapor compression distillation with maximum use of waste heat. Desalination 1981, 38, 3-12. [CrossRef]

185. Khoshrou, I.; Jafari Nasr, M.R.; Bakhtari, K. New opportunities in mass and energy consumption of the Multi-Stage Flash Distillation type of brackish water desalination process. Sol. Energy 2017, 153, 115-125. [CrossRef]

186. El-Ghonemy, A.M.K. Performance test of a sea water multi-stage flash distillation plant: Case study. Alexandria Eng. J. 2018, 57, 2401-2413. [CrossRef]

187. Bamufleh, H.; Abdelhady, F.; Baaqeel, H.M.; El-Halwagi, M.M. Optimization of multi-effect distillation with brine treatment via membrane distillation and process heat integration. Desalination 2017, 408, 110-118. [CrossRef]

188. Ortega-Delgado, B.; Palenzuela, P.; Alarcón-Padilla, D.C. Parametric study of a multi-effect distillation plant with thermal vapor compression for its integration into a Rankine cycle power block. Desalination 2016, 394, 18-29. [CrossRef] 
189. Qi, C.; Wang, X.; Feng, H.; Lv, Q. Performance analysis of low-temperature multi-effect distillation system under different feeding modes. Appl. Therm. Eng. 2017, 112, 1452-1459. [CrossRef]

190. Tarpani, R.R.Z.; Miralles-Cuevas, S.; Gallego-Schmid, A.; Cabrera-Reina, A.; Cornejo-Ponce, L. Environmental assessment of sustainable energy options for multi-effect distillation of brackish water in isolated communities. J. Clean. Prod. 2019, 213, 1371-1379. [CrossRef]

191. Patel, S.; Finan, M.A. New antifoulants for deposit control in MSF and MED plants. Desalination 1999, 124, 63-74. [CrossRef]

192. Morin, O.J. Design and operating comparison of MSF and MED systems. Desalination 1993, 93, 69-109. [CrossRef]

193. Raluy, G.; Serra, L.; Uche, J. Life cycle assessment of MSF, MED and RO desalination technologies. Energy 2006, 31, 2361-2372. [CrossRef]

194. Kabeel, A.E.; Hamed, M.H.; Omara, Z.M.; Sharshir, S.W. Water Desalination Using a HumidificationDehumidification Technique-A Detailed Review. Nat. Resour. 2013, 04, 286-305. [CrossRef]

195. Hamed, M.H.; Kabeel, A.E.; Omara, Z.M.; Sharshir, S.W. Mathematical and experimental investigation of a solar humidification-dehumidification desalination unit. Desalination 2015, 358, 9-17. [CrossRef]

196. Yildirim, C.; Solmuş, I. A parametric study on a humidification-dehumidification (HDH) desalination unit powered by solar air and water heaters. Energy Convers. Manag. 2014, 86, 568-575. [CrossRef]

197. Al-Hallaj, S.; Parekh, S.; Farid, M.M.; Selman, J.R. Solar desalination with humidification-dehumidification cycle: Review of economics. Desalination 2006, 195, 169-186. [CrossRef]

198. Parekh, S.; Farid, M.M.; Selman, J.R.; Al-Hallaj, S. Solar desalination with a humidification-dehumidification technique-A comprehensive technical review. Desalination 2004, 160, 167-186. [CrossRef]

199. Hutchens, C.F.; Long, D.A. Vapor Compression Distillation Urine Processor Lessons Learned from Development and Life Testing. In Proceedings of the International Conference On Environmental Systems, Denver, CO, USA, 12-15 July 2010; Volume 1. [CrossRef]

200. Wenten, I.; Aryanti, P.; Hakim, A. Scale-up Strategies for Membrane-Based Desalination Processes: A Review. J. Menbrane Sci. Res. 2016, 2, 42-58. [CrossRef]

201. Hosseini, M.; Azamat, J.; Erfan-Niya, H. Improving the performance of water desalination through ultra-permeable functionalized nanoporous graphene oxide membrane. Appl. Surf. Sci. 2018, 427, 1000-1008. [CrossRef]

202. Chen, W.; Chen, S.; Liang, T.; Zhang, Q.; Fan, Z.; Yin, H.; Huang, K.W.; Zhang, X.; Lai, Z.; Sheng, P. High-flux water desalination with interfacial salt sieving effect in nanoporous carbon composite membranes. Nat. Nanotechnol. 2018, 13, 345-350. [CrossRef] [PubMed]

203. Zhu, Y.; Gupta, K.M.; Liu, Q.; Jiang, J.; Caro, J.; Huang, A. Synthesis and seawater desalination of molecular sieving zeolitic imidazolate framework membranes. Desalination 2016, 385, 75-82. [CrossRef]

204. Werber, J.R.; Osuji, C.O.; Elimelech, M. Materials for next-generation desalination and water purification membranes. Nat. Rev. Mater. 2016, 1, 16018. [CrossRef]

205. Xu, K.; Feng, B.; Zhou, C.; Huang, A. Synthesis of highly stable graphene oxide membranes on polydopamine functionalized supports for seawater desalination. Chem. Eng. Sci. 2016, 146, 159-165. [CrossRef]

206. Zhang, C.; Zhang, K.; Cao, Y.; Koros, W.J. Composite Carbon Molecular Sieve Hollow Fiber Membranes: Resisting Support Densification via Silica Particle Stabilization. Ind. Eng. Chem. Res. 2018, 57, 16051-16058. [CrossRef]

207. Cay-Durgun, P.; Lind, M.L. Nanoporous materials in polymeric membranes for desalination. Curr. Opin. Chem. Eng. 2018, 20, 19-27. [CrossRef]

208. Selatile, M.K.; Ray, S.S.; Ojijo, V.; Sadiku, R. Recent developments in polymeric electrospun nanofibrous membranes for seawater desalination. RSC Adv. 2018, 8, 37915-37938. [CrossRef]

209. Ahmadvand, S.; Elahifard, M.; Jabbarzadeh, M.; Mirzanejad, A.; Pflughoeft, K.; Abbasi, B.; Abbasi, B. Bacteriostatic Effects of Apatite-Covered $\mathrm{Ag} / \mathrm{AgBr} / \mathrm{TiO}_{2}$ Nanocomposite in the Dark: Anomaly in Bacterial Motility. J. Phys. Chem. B 2019, 123, 787-791. [CrossRef] [PubMed]

210. Hilal, N.; Al-Zoubi, H.; Darwish, N.A.; Mohammad, A.W.; Abu Arabi, M. A comprehensive review of nanofiltration membranes: Treatment, pretreatment, modelling, and atomic force microscopy. Desalination 2004, 170, 281-308. [CrossRef]

211. Alkhudhiri, A.; Darwish, N.; Hilal, N. Membrane distillation: A comprehensive review. Desalination 2012, 287, 2-18. [CrossRef] 
212. Matsuura, T. Progress in membrane scince and technology for seawater desalination - A review. Desalination 2001, 134, 47-54. [CrossRef]

213. Malaeb, L.; Ayoub, G.M. Reverse osmosis technology for water treatment: State of the art review. Desalination 2011, 267, 1-8. [CrossRef]

214. Soltanieh, M.; Gill, W.N. Review of reverse osmosis membranes and transport models. Chem. Eng. Commun. 1981, 12, 279-363. [CrossRef]

215. Greenlee, L.F.; Lawler, D.F.; Freeman, B.D.; Marrot, B.; Moulin, P. Reverse osmosis desalination: Water sources, technology, and today's challenges. Water Res. 2009, 43, 2317-2348. [CrossRef] [PubMed]

216. Ghaffour, N.; Lattemann, S.; Missimer, T.; Ng, K.C.; Sinha, S.; Amy, G. Renewable energy-driven innovative energy-efficient desalination technologies. Appl. Energy 2014, 136, 1155-1165. [CrossRef]

217. Tzen, E.; Morris, R. Renewable energy sources for desalination. Sol. Energy 2003, 75, 375-379. [CrossRef]

218. Karimi, L.; Abkar, L.; Aghajani, M.; Ghassemi, A. Technical feasibility comparison of off-grid PV-EDR and PV-RO desalination systems via their energy consumption. Sep. Purif. Technol. 2015, 151, 82-94. [CrossRef]

219. Kim, M.M.; Lin, N.H.; Lewis, G.T.; Cohen, Y. Surface nano-structuring of reverse osmosis membranes via atmospheric pressure plasma-induced graft polymerization for reduction of mineral scaling propensity. J. Memb. Sci. 2010, 354, 142-149. [CrossRef]

220. Michaels, A.S. Membranes, membrane processes, and their applications: Needs, unsolved problems, and challenges of the 1990's. Desalination 1990, 77, 5-34. [CrossRef]

221. Herzberg, M.; Elimelech, M. Biofouling of reverse osmosis membranes: Role of biofilm-enhanced osmotic pressure. J. Memb. Sci. 2007, 295, 11-20. [CrossRef]

222. Han, G.; Zhang, S.; Li, X.; Chung, T.S. Progress in pressure retarded osmosis (PRO) membranes for osmotic power generation. Prog. Polym. Sci. 2014, 51, 1-27. [CrossRef]

223. Abou Rayan, M.; Khaled, I. Seawater desalination by reverse osmosis (case study). Desalination 2003, 153, 245-251. [CrossRef]

224. Wittholz, M.K.; O'Neill, B.K.; Colby, C.B.; Lewis, D. Estimating the cost of desalination plants using a cost database. Desalination 2008, 229, 10-20. [CrossRef]

225. Côté, P.; Siverns, S.; Monti, S. Comparison of membrane-based solutions for water reclamation and desalination. Desalination 2005, 182, 251-257. [CrossRef]

226. Maskan, F.; Wiley, D.E.; Johnston, L.P.M.; Clements, D.J. Optimal design of reverse osmosis module networks. AIChE J. 2000, 46, 946-954. [CrossRef]

227. Jamaly, S.; Darwish, N.N.; Ahmed, I.; Hasan, S.W. A short review on reverse osmosis pretreatment technologies. Desalination 2014, 354, 30-38. [CrossRef]

228. Liu, C.; Rainwater, K.; Song, L. Energy analysis and efficiency assessment of reverse osmosis desalination process. Desalination 2011, 276, 352-358. [CrossRef]

229. Walha, K.; Amar, R.B.; Firdaous, L.; Quéméneur, F.; Jaouen, P. Brackish groundwater treatment by nanofiltration, reverse osmosis and electrodialysis in Tunisia: performance and cost comparison. Desalination 2007, 207, 95-106. [CrossRef]

230. Schulze, K.D.; Hart, S.M.; Marshall, S.L.; O’Bryan, C.S.; Urueña, J.M.; Pitenis, A.A.; Sawyer, W.G.; Angelini, T.E. Polymer Osmotic Pressure in Hydrogel Contact Mechanics. Biotribology 2017, 11, 3-7. [CrossRef]

231. She, Q.; Wei, J.; Ma, N.; Sim, V.; Fane, A.G.; Wang, R.; Tang, C.Y. Fabrication and characterization of fabric-reinforced pressure retarded osmosis membranes for osmotic power harvesting. J. Memb. Sci. 2016, 504, 75-88. [CrossRef]

232. Sahebi, S.; Phuntsho, S.; Eun Kim, J.; Hong, S.; Kyong Shon, H. Pressure assisted fertiliser drawn osmosis process to enhance final dilution of the fertiliser draw solution beyond osmotic equilibrium. J. Memb. Sci. 2015, 481, 63-72. [CrossRef]

233. Warsinger, D.M.; Tow, E.W.; Nayar, K.G.; Maswadeh, L.A.; Lienhard V, J.H. Energy efficiency of batch and semi-batch (CCRO) reverse osmosis desalination. Water Res. 2016, 106, 272-282. [CrossRef] [PubMed]

234. Eshoul, N.M.; Agnew, B.; Al-Weshahi, M.A.; Atab, M.S. Exergy analysis of a two-pass Reverse Osmosis (RO) desalination unit with and without an energy recovery turbine (ERT) and pressure exchanger (PX). Energies 2015, 8, 6910-6925. [CrossRef]

235. Qasem, N.A.A.; Qureshi, B.A.; Zubair, S.M. Improvement in design of electrodialysis desalination plants by considering the Donnan potential. Desalination 2018, 441, 62-76. [CrossRef] 
236. Qureshi, B.A.; Zubair, S.M. Design of electrodialysis desalination plants by considering dimensionless groups and variable equivalent conductivity. Desalination 2018, 430, 197-207. [CrossRef]

237. Nakayama, A.; Sano, Y.; Bai, X.; Tado, K. A boundary layer analysis for determination of the limiting current density in an electrodialysis desalination. Desalination 2017, 404, 41-49. [CrossRef]

238. Wright, N.C.; Shah, S.R.; Amrose, S.E.; Winter, A.G. A robust model of brackish water electrodialysis desalination with experimental comparison at different size scales. Desalination 2018, 443, 27-43. [CrossRef]

239. Tado, K.; Sakai, F.; Sano, Y.; Nakayama, A. An analysis on ion transport process in electrodialysis desalination. Desalination 2016, 378, 60-66. [CrossRef]

240. Shah, S.R.; Walter, S.L.; Winter, A.G. Using feed-forward voltage-control to increase the ion removal rate during batch electrodialysis desalination of brackish water. Desalination 2019, 457, 62-74. [CrossRef]

241. Khan, M.I.; Mondal, A.N.; Tong, B.; Jiang, C.; Emmanuel, K.; Yang, Z.; Wu, L.; Xu, T. Development of BPPO-based anion exchange membranes for electrodialysis desalination applications. Desalination 2016, 391, 61-68. [CrossRef]

242. Nam, D.H.; Choi, K.S. Electrochemical Desalination Using Bi/BiOCl Electrodialysis Cells. ACS Sustain. Chem. Eng. 2018, 6, 15455-15462. [CrossRef]

243. Fernandez-Gonzalez, C.; Dominguez-Ramos, A.; Ibañez, R.; Irabien, A. Desalination by Renewable Energy-Powered Electrodialysis Processes. Curr. Trends Futur. Dev. Membr. 2018, 111-131.

244. Tufa, R.A.; Curcio, E.; Brauns, E.; van Baak, W.; Fontananova, E.; Di Profio, G. Membrane Distillation and Reverse Electrodialysis for Near-Zero Liquid Discharge and low energy seawater desalination. J. Memb. Sci. 2015, 496, 325-333. [CrossRef]

245. Mei, Y.; Tang, C.Y. Recent developments and future perspectives of reverse electrodialysis technology: A review. Desalination 2018, 425, 156-174. [CrossRef]

246. Xu, T.; Huang, C. Electrodialysis-Based separation technologies: A critical review. AIChE J. 2008, 54, 3147-3159. [CrossRef]

247. Tongwen, X. Electrodialysis processes with bipolar membranes (EDBM) in environmental protection A review. Resour. Conserv. Recycl. 2002, 37, 1-22. [CrossRef]

248. Burn, S.; Hoang, M.; Zarzo, D.; Olewniak, F.; Campos, E.; Bolto, B.; Barron, O. Desalination techniques A review of the opportunities for desalination in agriculture. Desalination 2015, 364, 2-16. [CrossRef]

249. Ali, M.T.; Fath, H.E.S.; Armstrong, P.R. A comprehensive techno-economical review of indirect solar desalination. Renew. Sustain. Energy Rev. 2011, 15, 4187-4199. [CrossRef]

250. Mezher, T.; Fath, H.; Abbas, Z.; Khaled, A. Techno-economic assessment and environmental impacts of desalination technologies. Desalination 2011, 266, 263-273. [CrossRef]

251. Huang, C.; Xu, T.; Zhang, Y.; Xue, Y.; Chen, G. Application of electrodialysis to the production of organic acids: State-of-the-art and recent developments. J. Memb. Sci. 2007, 288, 1-12. [CrossRef]

252. Höpner, T.; Windelberg, J. Elements of environmental impact studies on coastal desalination plants. Desalination 1997, 108, 11-18. [CrossRef]

253. Porada, S.; Weinstein, L.; Dash, R.; Van Der Wal, A.; Bryjak, M.; Gogotsi, Y.; Biesheuvel, P.M. Water desalination using capacitive deionization with microporous carbon electrodes. ACS Appl. Mater. Interfaces 2012, 4, 1194-1199. [CrossRef]

254. Huang, D.; Liu, W.; Xu, Y.; Wu, Z.; Zheng, H.; Hu, N.; Lu, K.; Jia, L. Desalination for enhancing the recovery of creatine from its wastewater by foam fractionation. J. Mol. Liq. 2018, 255, 447-453. [CrossRef]

255. Arconada, B.; Delgado, P.; García, Á. Minimizing environmental risks on constructing marine pipelines: Aguilas desalination plant. Desalin. Water Treat. 2013, 51, 246-261. [CrossRef]

256. Davies, P.A. Wave-powered desalination: Resource assessment and review of technology. Desalination 2005, 186, 97-109. [CrossRef]

257. Davies, P.A.; Wayman, J.; Alatta, C.; Nguyen, K.; Orfi, J. A desalination system with efficiency approaching the theoretical limits. Desalin. Water Treat. 2016, 57, 23206-23216. [CrossRef]

258. Kasaeian, A.; Rajaee, F.; Yan, W.M. Osmotic desalination by solar energy: A critical review. Renew. Energy 2019, 134, 1473-1490. [CrossRef]

259. Ebrahimi, K.; Jones, G.F.; Fleischer, A.S. A review of data center cooling technology, operating conditions and the corresponding low-grade waste heat recovery opportunities. Renew. Sustain. Energy Rev. 2014, 31, 622-638. [CrossRef] 
260. Shu, G.; Liang, Y.; Wei, H.; Tian, H.; Zhao, J.; Liu, L. A review of waste heat recovery on two-stroke IC engine aboard ships. Renew. Sustain. Energy Rev. 2013, 19, 385-401. [CrossRef]

261. Gude, V.G. Energy storage for desalination processes powered by renewable energy and waste heat sources. Appl. Energy 2015, 137, 877-898. [CrossRef]

262. Eltawil, M.A.; Zhengming, Z.; Yuan, L. A review of renewable energy technologies integrated with desalination systems. Renew. Sustain. Energy Rev. 2009, 13, 2245-2262. [CrossRef]

263. Miró, L.; Gasia, J.; Cabeza, L.F. Thermal energy storage (TES) for industrial waste heat (IWH) recovery: A review. Appl. Energy 2016, 179, 284-301. [CrossRef]

264. Song, L.; Li, B.; Sirkar, K.K.; Gilron, J.L. Direct contact membrane distillation-based desalination: Novel membranes, devices, larger-scale studies, and a model. Ind. Eng. Chem. Res. 2007, 46, 2307-2323. [CrossRef]

265. Singh, D.; Sirkar, K.K. Desalination of brine and produced water by direct contact membrane distillation at high temperatures and pressures. J. Memb. Sci. 2012, 389, 380-388. [CrossRef]

266. Essalhi, M.; Khayet, M. Self-sustained webs of polyvinylidene fluoride electrospun nanofibers at different electrospinning times: 1. Desalination by direct contact membrane distillation. J. Memb. Sci. 2013, 433, 167-179. [CrossRef]

267. Eslamimanesh, A.; Hatamipour, M.S. Mathematical modeling of a direct contact humidification-dehumidification desalination process. Desalination 2009, 237, 296-304. [CrossRef]

268. Sideman, S.; Isenberg, J. Direct contact heat transfer with change of phase: bubble growth in three-phase systems. Desalination 1967, 2, 207-214. [CrossRef]

269. Zhang, X.; Liu, Y.; Wen, X.; Li, C.; Hu, X. Low-grade waste heat driven desalination with an open loop heat pipe. Energy 2018, 163, 221-228. [CrossRef]

270. Alkaisi, A.; Mossad, R.; Sharifian-Barforoush, A. A Review of the Water Desalination Systems Integrated with Renewable Energy. Energy Procedia 2017, 110, 268-274. [CrossRef]

271. Goosen, M.F.A.; Mahmoudi, H.; Ghaffour, N.; Bundschuh, J.; Al Yousef, Y. A critical evaluation of renewable energy technologies for desalination. In Proceedings of the Application of Materials Science and Environmental Materials Phuket Island, Thailand, 1-3 October 2015.

272. Ali, A.; Tufa, R.A.; Macedonio, F.; Curcio, E.; Drioli, E. Membrane technology in renewable-energy-driven desalination. Renew. Sustain. Energy Rev. 2018, 81, 1-21. [CrossRef]

273. Chandrashekara, M.; Yadav, A. Water desalination system using solar heat: A review. Renew. Sustain. Energy Rev. 2017, 67, 1308-1330.

274. Schwarzer, T.; Bart, H.J. Mass and Heat Transfer at Different Heat Exchange Surfaces and Their Suitability for Use in Thermal Desalination Plants. Open Chem. Eng. J. 2016, 10, 74-86. [CrossRef]

275. Dastgerdi, H.R.; Whittaker, P.B.; Chua, H.T. New MED based desalination process for low grade waste heat. Desalination 2016, 395, 57-71. [CrossRef]

276. Bush, J.A.; Vanneste, J.; Gustafson, E.M.; Waechter, C.A.; Jassby, D.; Turchi, C.S.; Cath, T.Y. Prevention and management of silica scaling in membrane distillation using $\mathrm{pH}$ adjustment. J. Memb. Sci. 2018, 554, 366-377. [CrossRef]

277. Matin, A.; Rahman, F.; Shafi, H.Z.; Zubair, S.M. Scaling of reverse osmosis membranes used in water desalination: Phenomena, impact, and control; future directions. Desalination 2019, 455, 135-157. [CrossRef]

278. Piyadasa, C.; Ridgway, H.F.; Yeager, T.R.; Stewart, M.B.; Pelekani, C.; Gray, S.R.; Orbell, J.D. The application of electromagnetic fields to the control of the scaling and biofouling of reverse osmosis membranes - A review. Desalination 2017, 418, 19-34. [CrossRef]

279. Sharon, H.; Reddy, K.S. A review of solar energy driven desalination technologies. Renew. Sustain. Energy Rev. 2015, 41, 1080-1118. [CrossRef]

280. Efd Desalination Technology Solution-Eliminates Toxic Brine Discharge. Available online: http://efdcorp. com/solution/ (accessed on 20 April 2019).

281. Heck, N.; Lykkebo Petersen, K.; Potts, D.C.; Haddad, B.; Paytan, A. Predictors of coastal stakeholders' knowledge about seawater desalination impacts on marine ecosystems. Sci. Total Environ. 2018, 639, 785-792. [CrossRef]

282. Miller, J.E. Review of water resources and desalination techniques. Sandia national labs unlimited release report SAND-2003-0800. 2003. [CrossRef]

283. Owlad, M.; Aroua, M.K.; Daud, W.A.W.; Baroutian, S. Removal of hexavalent chromium-contaminated water and wastewater: A review. Water. Air. Soil Pollut. 2009, 200, 59-77. [CrossRef] 
284. Ghernaout, D.; Ghernaout, B.; Naceur, M.W. Embodying the chemical water treatment in the green chemistry-A review. Desalination 2011, 271, 1-10. [CrossRef]

285. Pang, Y.L.; Abdullah, A.Z.; Bhatia, S. Review on sonochemical methods in the presence of catalysts and chemical additives for treatment of organic pollutants in wastewater. Desalination 2011, 277, 1-14. [CrossRef]

286. Jin, W.; Du, H.; Zheng, S.; Zhang, Y. Electrochemical processes for the environmental remediation of toxic Cr(VI): A review. Electrochim. Acta 2016, 191, 1044-1055. [CrossRef]

287. Holkar, C.R.; Jadhav, A.J.; Pinjari, D.V.; Mahamuni, N.M.; Pandit, A.B. A critical review on textile wastewater treatments: Possible approaches. J. Environ. Manage. 2016, 182, 351-366. [CrossRef]

288. Shahmansouri, A.; Min, J.; Jin, L.; Bellona, C. Feasibility of extracting valuable minerals from desalination concentrate: A comprehensive literature review. J. Clean. Prod. 2015, 100, 4-16. [CrossRef]

289. Kang, G.D.; Cao, Y.M. Development of antifouling reverse osmosis membranes for water treatment: A review. Water Res. 2012, 46, 584-600. [CrossRef]

290. Matin, A.; Khan, Z.; Zaidi, S.M.J.; Boyce, M.C. Biofouling in reverse osmosis membranes for seawater desalination: Phenomena and prevention. Desalination 2011, 281, 1-16. [CrossRef]

291. Li, Q.; Mahendra, S.; Lyon, D.Y.; Brunet, L.; Liga, M.V.; Li, D.; Alvarez, P.J.J. Antimicrobial nanomaterials for water disinfection and microbial control: potential applications and implications. Water Res. 2008, 42, 4591-4602. [CrossRef] [PubMed]

292. Udriot, H.; Araque, A.; von Stockar, U. Azeotropic mixtures may be broken by membrane distillation. Chem. Eng. J. Biochem. Eng. J. 1994, 54, 87-93. [CrossRef]

293. Verma, A.K.; Dash, R.R.; Bhunia, P. A review on chemical coagulation/flocculation technologies for removal of colour from textile wastewaters. J. Environ. Manage. 2012, 93, 154-168. [CrossRef] [PubMed]

294. Song, Z.; Williams, C.J.; Edyvean, R.G.J. Treatment of tannery wastewater by chemical coagulation. Desalination 2004, 164, 249-259. [CrossRef]

295. Hoepner, T.; Lattemann, S. Chemical impacts from seawater desalination plants - A case study of the northern Red Sea. Desalination 2003, 152, 133-140. [CrossRef]

296. Padervand, M.; Salari, H.; Ahmadvand, S.; Gholami, M.R. Removal of an organic pollutant from waste water by photocatalytic behavior of $\mathrm{AgX} / \mathrm{TiO}_{2}$ loaded on mordenite nanocrystals. Res. Chem. Intermed. 2012, 38, 1975-1985. [CrossRef]

297. Elahifard, M.R.; Ahmadvand, S.; Mirzanejad, A. Effects of Ni-doping on the photo-catalytic activity of $\mathrm{TiO}_{2}$ anatase and rutile: Simulation and experiment. Mater. Sci. Semicond. Process. 2018, 84, 10-16. [CrossRef]

298. Ricker, J.D.; Mohammadrezaei, V.; Crippen, T.J.; Zell, A.M.; Geary, L.M. Nitrous Oxide Promoted Pauson-Khand Cycloadditions. Organometallics 2018, 37, 4556-4559. [CrossRef]

299. Khayet, M.; Mengual, J.I.; Matsuura, T. Porous hydrophobic/hydrophilic composite membranes: Application in desalination using direct contact membrane distillation. J. Memb. Sci. 2005, 252, 101-113. [CrossRef]

300. Ganesh, B.M.; Isloor, A.M.; Ismail, A.F. Enhanced hydrophilicity and salt rejection study of graphene oxide-polysulfone mixed matrix membrane. Desalination 2013, 313, 199-207. [CrossRef]

301. Prince, J.A.; Singh, G.; Rana, D.; Matsuura, T.; Anbharasi, V.; Shanmugasundaram, T.S. Preparation and characterization of highly hydrophobic poly(vinylidene fluoride) - Clay nanocomposite nanofiber membranes (PVDF-clay NNMs) for desalination using direct contact membrane distillation. J. Memb. Sci. 2012, 397-398, 80-86. [CrossRef]

302. Peng, P.; Fane, A.G.; Li, X. Desalination by membrane distillation adopting a hydrophilic membrane. Desalination 2005, 173, 45-54. [CrossRef]

303. Mahmoud, K.A.; Mansoor, B.; Mansour, A.; Khraisheh, M. Functional graphene nanosheets: The next generation membranes for water desalination. Desalination 2015, 356, 208-225. [CrossRef]

304. Schiermeier, Q. Water: Purification with a pinch of salt. Nature 2008, 452, 260-261. [CrossRef] [PubMed]

305. McGinnis, R.L.; Elimelech, M. Global challenges in energy and water supply: The promise of engineered osmosis. Environ. Sci. Technol. 2008, 42, 8625-8629. [CrossRef] [PubMed]

306. Li, Y.; Klausner, J.F.; Mei, R. Performance characteristics of the diffusion driven desalination process. Desalination 2006, 196, 188-209. [CrossRef]

307. Klausner, J.F.; Li, Y.; Darwish, M.; Mei, R. Innovative Diffusion Driven Desalination Process. J. Energy Resour. Technol. 2004, 126, 219. [CrossRef]

308. Klausner, J.F.; Li, Y.; Mei, R. Evaporative heat and mass transfer for the diffusion driven desalination process. Heat Mass Transf. und Stoffuebertragung 2006, 42, 528-536. [CrossRef] 
309. Alnaimat, F.; Klausner, J.F.; Mei, R. Transient dynamic response of solar diffusion driven desalination. Appl. Therm. Eng. 2013, 51, 520-528. [CrossRef]

310. Khan, J.R.; Klausner, J.F.; Ziegler, D.P.; Garimella, S.S. Diffusion Driven Desalination for Simultaneous Fresh Water Production and Desulfurization. J. Therm. Sci. Eng. Appl. 2010, 2, 031006. [CrossRef]

311. Alnaimat, F.; Klausner, J.F. Solar diffusion driven desalination for decentralized water production. Desalination 2012, 289, 35-44. [CrossRef]

312. Koschikowski, J.; Juülch, V.; Kec, T.; Hussein, N. Renewable Desalination: Technology Options for Islands; International Renewable Energy Agency: Abu Dhabi, United Arab Emirates, 2015; ISBN 978-92-95111-78-3.

313. Zhou, Y.; Tol, R.S.J. Evaluating the costs of desalination and water transport. Water Resour. Res. 2005, 41, 1-10. [CrossRef]

314. Sommariva, C.; Hogg, H.; Callister, K. Cost reduction and design lifetime increase in thermal desalination plants: Thermodynamic and corrosion resistance combined analysis for heat exchange tubes material selection. Desalination 2003, 158, 17-21. [CrossRef]

315. Midžić, I.; Štorga, M.; Marjanović, D. Energy quality hierarchy and "transformity" in evaluation of product's working principles. Procedia CIRP 2014, 15, 300-305. [CrossRef]

316. Blandin, G.; Verliefde, A.R.D.; Comas, J.; Rodriguez-Roda, I.; Le-Clech, P. Efficiently combining water reuse and desalination through forward osmosis-reverse osmosis (FO-RO) hybrids: A critical review. Membranes (Basel) 2016, 6, 37. [CrossRef]

317. Quist-Jensen, C.A.; Macedonio, F.; Drioli, E. Membrane technology for water production in agriculture: Desalination and wastewater reuse. Desalination 2015, 364, 17-32. [CrossRef]

318. Bennett, A. Cost effective desalination: Innovation continues to lower desalination costs. Filtr. Sep. 2011, 48, 24-27. [CrossRef]

319. Tufa, R.A. Perspectives on environmental ethics in sustainability of membrane based technologies for water and energy production. Environ. Technol. Innov. 2015, 4, 182-193. [CrossRef]

320. Zak, G.M.; Mancini, N.D.; Mitsos, A. Integration of thermal desalination methods with membrane-based oxy-combustion power cycles. Desalination 2013, 311, 137-149. [CrossRef]

321. Salimi, M.; Amidpour, M. Modeling, simulation, parametric study and economic assessment of reciprocating internal combustion engine integrated with multi-effect desalination unit. Energy Convers. Manag. 2017, 138, 299-311. [CrossRef]

322. Al-Karaghouli, A.; Kazmerski, L.L. Energy consumption and water production cost of conventional and renewable-energy-powered desalination processes. Renew. Sustain. Energy Rev. 2013, 24, 343-356. [CrossRef]

323. Fu, P.; Johnson, S.M.; Carrigan, C.R. Using Fully Coupled Hydro-Geomechanical Numerical Test Bed To Study Reservoir Stimulation With Low Hydraulic Pressure. In Proceedings of the 37 Stanford Geothermal Workshop, Stanford, CA, USA, 30 Jnauary 1-Feburary 2012.

324. Rimedio, M.; Shannon, C.; Monti, L.; Lerza, A.; Roberts, M.; Quiroga, J. Interference Behavior Analysis in Vaca Muerta Shale Oil Development, Loma Campana Field, Argentina. In Proceedings of the 3rd Unconventional Resources Technology Conference, San Antonio, TX, USA, 20-22 July 2015.

325. Cuss, R.; Harrington, J.; Graham, C.; Noy, D. Observations of pore pressure in clay-rich materials; Implications for the concept of effective stress applied to unconventional hydrocarbons. Energy Procedia 2014, 59, 59-66. [CrossRef]

326. Wilson, H.M.; Rahman A.R., S.; Parab, A.E.; Jha, N. Ultra-low cost cotton based solar evaporation device for seawater desalination and waste water purification to produce drinkable water. Desalination 2019, 456, 85-96. [CrossRef]

327. Gan, Q.; Zhang, T.; Chen, R.; Wang, X.; Ye, M. Simple, Low-Dose, Durable, and Carbon-Nanotube-Based Floating Solar Still for Efficient Desalination and Purification. ACS Sustain. Chem. Eng. 2019, 7, 3925-3932. [CrossRef]

328. Rashidi, S.; Karimi, N.; Mahian, O.; Abolfazli Esfahani, J. A concise review on the role of nanoparticles upon the productivity of solar desalination systems. J. Therm. Anal. Calorim. 2019, 135, 1145-1159. [CrossRef]

329. Li, X.; Xu, G.; Peng, G.; Yang, N.; Yu, W.; Deng, C. Efficiency enhancement on the solar steam generation by wick materials with wrapped graphene nanoparticles. 2019. Available online: https://arxiv.org/abs/1901.01683 (accessed on 20 April 2019). 
330. Kiriarachchi, H.D.; Awad, F.S.; Hassan, A.A.; Bobb, J.A.; Lin, A.; El-Shall, M.S. Plasmonic chemically modified cotton nanocomposite fibers for efficient solar water desalination and wastewater treatment. Nanoscale 2018, 10, 18531-18539. [CrossRef]

331. Yang, P.; Liu, K.; Chen, Q.; Li, J.; Duan, J.; Xue, G.; Xu, Z.; Xie, W.; Zhou, J. Solar-driven simultaneous steam production and electricity generation from salinity. Energy Environ. Sci. 2017, 10, 1923-1927. [CrossRef]

332. Hou, B.; Kong, D.; Qian, J.; Yu, Y.; Cui, Z.; Liu, X.; Wang, J.; Mei, T.; Li, J.; Wang, X. Flexible and portable graphene on carbon cloth as a power generator for electricity generation. Carbon N. Y. 2018, 140, 488-493. [CrossRef]

333. Liu, C.; Huang, J.; Hsiung, C.-E.; Tian, Y.; Wang, J.; Han, Y.; Fratalocchi, A. High-Performance Large-Scale Solar Steam Generation with Nanolayers of Reusable Biomimetic Nanoparticles. Adv. Sustain. Syst. 2017, 1, 1600013. [CrossRef]

334. Huang, L.; Pei, J.; Jiang, H.; Hu, X. Water desalination under one sun using graphene-based material modified PTFE membrane. Desalination 2018, 442,1-7. [CrossRef]

335. Li, X.; Lin, R.; Ni, G.; Xu, N.; Hu, X.; Zhu, B.; Lv, G.; Li, J.; Zhu, S.; Zhu, J. Three-dimensional artificial transpiration for efficient solar waste-water treatment. Natl. Sci. Rev. 2018, 5, 70-77. [CrossRef]

336. Liu, K.K.; Jiang, Q.; Tadepalli, S.; Raliya, R.; Biswas, P.; Naik, R.R.; Singamaneni, S. Wood-Graphene Oxide Composite for Highly Efficient Solar Steam Generation and Desalination. ACS Appl. Mater. Interfaces 2017, 9 , 7675-7681. [CrossRef] [PubMed]

337. Yang, J.; Pang, Y.; Huang, W.; Shaw, S.K.; Schiffbauer, J.; Pillers, M.A.; Mu, X.; Luo, S.; Zhang, T.; Huang, Y.; et al. Functionalized Graphene Enables Highly Efficient Solar Thermal Steam Generation. ACS Nano 2017, 11, 5510-5518. [CrossRef]

338. Ren, H.; Tang, M.; Guan, B.; Wang, K.; Yang, J.; Wang, F.; Wang, M.; Shan, J.; Chen, Z.; Wei, D.; et al. Hierarchical Graphene Foam for Efficient Omnidirectional Solar-Thermal Energy Conversion. Adv. Mater. 2017, 29, 1702590. [CrossRef] [PubMed]

339. Xu, W.; Hu, X.; Zhuang, S.; Wang, Y.; Li, X.; Zhou, L.; Zhu, S.; Zhu, J. Flexible and Salt Resistant Janus Absorbers by Electrospinning for Stable and Efficient Solar Desalination. Adv. Energy Mater. 2018, 8, 1702884. [CrossRef]

340. Xu, Y.; Ma, J.; Liu, D.; Xu, H.; Cui, F.; Wang, W. Origami system for efficient solar driven distillation in emergency water supply. Chem. Eng. J. 2019, 356, 869-876. [CrossRef]

341. Li, Y.; Gao, T.; Yang, Z.; Chen, C.; Luo, W.; Song, J.; Hitz, E.; Jia, C.; Zhou, Y.; Liu, B.; et al. 3D-Printed, All-in-One Evaporator for High-Efficiency Solar Steam Generation under 1 Sun Illumination. Adv. Mater. 2017, 29, 1700981. [CrossRef]

(C) 2019 by the authors. Licensee MDPI, Basel, Switzerland. This article is an open access article distributed under the terms and conditions of the Creative Commons Attribution (CC BY) license (http://creativecommons.org/licenses/by/4.0/). 